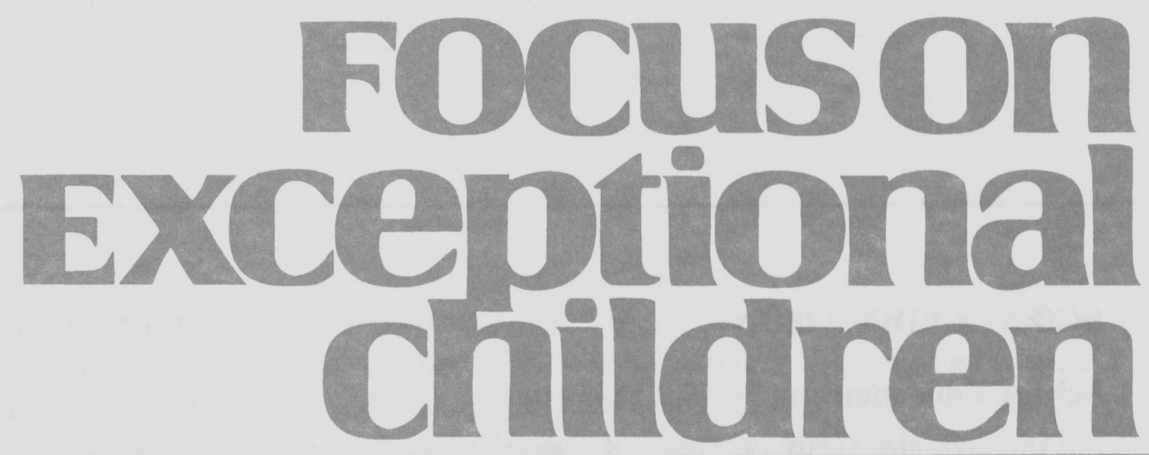

\title{
Science and Social Studies for Students With Disabilities
}

\author{
Thomas E. Scruggs, Margo A. Mastropieri, and Cynthia M. Okolo
}

Science and social studies have much to offer to all learners-including those with disabilities. However, instruction in these subjects has often been overlooked in the quest to better understand and improve leaning in English/language arts and mathematics. As we demonstrate in this paper, science and social studies help students attain skills, information, and dispositions that are important for success in school and everyday life. Furthermore, these subjects offer opportunities for students to learn and apply literacy and mathematics skills, engage in authentic problem solving and inquiry, and experience success in the general education classroom. We begin by discussing the nature of learning in science and social studies as well as the interaction of learners with the curriculum. We then review instructional practices for improving the performance of students with disabilities in each of these subject areas.

\section{SCIENCE AND SOCIAL STUDIES FOR STUDENTS WITH DISABILITIES}

Over the years, content area learning, including science and social studies, has received less emphasis in special education literature than basic instruction in the form of literacy and early math skills (Mastropieri et al., in press). Nevertheless, with the increased emphases on inclusion, accountability, and high stakes testing, content area instruction has acquired renewed importance (Lenz, Deshler, \& Kissam, 2004). Beyond the obvious advantages to school success, enhanced understanding of human society and the physical universe can be expected to improve the quality of the lives of students with disabilities.

In this article, we discuss research in science and social studies education for students with disabilities. Although there are many commonalities in these two bodies of literature, each addresses specific challenges as researchers have attempted to adapt instructional methods and curriculum materials to the characteristics of learners with special needs. Therefore, we first discuss each area separately and then draw conclusions regarding commonalities in science and social studies education at the end of the article.

Dr. Scruggs is Professor and Director of the $\mathrm{PhD}$ in the Education program in the College of Education and Human Development at George Mason University. Dr. Mastropieri is Professor of Special Education in the College of Education and Human Development at George Mason University. Dr. Okolo is Professor of Special Education in the College of Education at Michigan State University. 


\section{SCIENCE EDUCATION}

\section{Science Education and Special Education}

Although the focus of much of special education has been on the acquisition of basic skills that are essential to academic learning, we have no doubt that science is of particular importance to students with disabilities, which in fact provides important insights into our general understanding of science education. For example, some years ago we were confronted with a fourth-grade science classroom undertaking a "small things" unit, for which microscopes were frequently employed. This particular class included a totally blind student, and teachers early on had suggested this student be excused from this unit of study. The parentsrightly, we think-refused this suggestion and insisted that their child be taught alongside her peers. This situation required teachers to rethink the objectives of the class, to discriminate clearly between the mechanics and the content of science learning, and to carefully prioritize the importance of this content. As physical models of small things and

\section{FOCusOn Exceptional children}

ISSN 0015-511X FOCUS ON EXCEPTIONAL CHILDREN (USPS 203-360) is published monthly except June, July, and August as a service to teachers, special educators, curriculum specialists, administrators, and those concerned with the special education of exceptional children. This publication is annotated and indexed by the ERIC Clearinghouse on Handicapped and Gifted Children for publication in the monthly Current Index to Journals in Education (CIJE) and the quarterly index, Exceptional Children Education Resources (ECER). The full text of Focus on Exceptional Children is also available in the electronic versions of the Education Index. It is also available in microfilm from Serials Acquisitions, National Archive Publishing Company, P.O. Box 998, Ann Arbor, MI 48106-0998. Subscription rates: individual, \$42 per year; institutions, \$56 per year. Copyright (C) 2008, Love Publishing Company. All rights reserved. Reproduction in whole or part without written permission is prohibited. Printed in the United States of America. Periodical postage is paid at Denver, Colorado. POSTMASTER: Send address changes to:

Love Publishing Company

Executive and Editorial Office P.O. Box 22353

Denver, Colorado 80222

Telephone (303) 221-7333

\section{EDITORIAL BOARD}

Lisa Dieker

University of Central Florida
Paula Maccini University of Maryland

Marleen Pugach

University of Wisconsin-Milwaukee

Carrie E. Watterson Senior Editor
Stanley F. Love Publisher accompanying explanations were constructed, it became clear that such reflective consideration of course content improved instruction for all students. When it also became clear that a student with some fine motor difficulties could not easily stain specimens and prepare slides, the previously prioritized objectives (the relative importance of slide staining vs. understanding cellular structure) were helpful in dealing with this issue.

This example provides insight, not simply for students with disabilities, but also for our understanding of the nature of science. Science has always been concerned with advancement in understanding beyond the sensory and physical limitations that affect and challenge us all-not simply those with disabilities. To advance our knowledge, it has always been important for us to develop adaptations and enhancements to our own senses and physical abilities; these adaptations have helped us develop our ability to think and to imagine and to continue to seek rational and logical explanations for the observed universe (Scruggs, 2004).

As another example, we encountered a student with a terminal illness who was being integrated into an inclusive science classroom studying the life cycle. Not only did this unit underscore the sometimes unique (and in this case, heartbreaking) relevance of science for students with disabilities, it also provides insight on the importance of science education - that is, that science education is not necessarily a kind of pretraining for those who would pursue careers in the sciences, but that it can broaden understanding of the universe and our role in it, and that science can enhance our lives directly at the time we learn it (Scruggs, 2004).

\section{Characteristics of Science Curriculum and Characteristics of the Learner}

Instruction may be viewed as concerned intimately with the interaction between curriculum and learner characteristics (Mastropieri \& Scruggs, 2010; Scruggs \& Mastropieri, $1992 b)$. In the case of science education, students with disabilities may respond differentially, given the nature of the science curriculum. For example, it has been seen that textbook-based science learning involves very substantial amounts of vocabulary learning (e.g., prokaryotic heterotroph, radial symmetry, saprophytic) and learning and memory of verbally based facts. These are usually presented in lecture and worksheet activities and require independent study from text (Scruggs \& Mastropieri, 1994a). Such approaches to science education typically emphasize breadth of content over depth of understanding as well as the acquisition of verbal associates and other factual material. Always common in schools, text-based approaches have gained in importance during the current era of standardsbased learning and high-stakes testing (Frase-Blunt, 2000; Huber \& Moore, 2002). 
Considering the characteristics of students with disabilities in relation to the characteristics of text-based science learning, it can be seen that students with difficulties in verbal learning, literacy and text comprehension, and independent study strategies could be expected to have considerable difficulty with such an approach. In fact, such difficulties are common among students with mild disabilities (Mastropieri \& Scruggs, 1994; Scruggs \& Mastropieri, 1993). For example, Cawley and Parmar (2001) concluded that many students with disabilities lack the literacy skills necessary for learning effectively from science textbooks, a finding frequently reported in the literature (see also Carlisle, 1993a, 1999; Cawley, Miller, \& Carr, 1990). Although some students may benefit from the structure, the independence, and the efficient, systematic approach to content coverage associated with such learning, text-based science learning does not appear to interact positively overall with the characteristics of students with mild disabilities. For an example, consider a passage from a high school chemistry text:

\begin{abstract}
In most polymers, like polyethylene and cellulose, the monomers are all identical. In other cases, such as proteins, different monomers may be combined. Although the amino acid monomers that make up proteins appear to be very different, each one has an amino functional group and an organic acid functional group, so the monomers all link in the same way, forming a "backbone" of carbon, nitrogen, and oxygen atoms. A polymer with three amino acids is called a tripeptide. (Tocci \& Viehland, 1996, p. 257)
\end{abstract}

Not only does this passage appear extraordinarily dense, it is also interesting to note that this passage occupies perhaps $15 \%$ of the space of one page of a book that is overall 848 pages long! Given this example, it may not be surprising that some science textbooks have been found to contain more new vocabulary words than some foreign language textbooks (Groves, 1995; Yager, 1983).

On the other hand, hands-on approaches are also employed in many cases in science classes. These approaches focus more on student experimentation and learning from direct manipulation of physical materials (e.g., microscopes, plants and animals, rocks and minerals, electrical circuits), rather than from textbooks. To some extent, we might expect hands-on science curriculum approaches to pose some problems for students with mild disabilities because of the demands sometimes placed on learner insight, possible problems attending to relevant content dimensions, and the temptations for off-task behavior posed by a the presence of a variety of manipulative materials. On the other hand, students might be expected to benefit from the physical presence of concrete materials, the opportunity to learn from experience, and the deemphasis on unreadable (for some) text and large amounts of vocabulary and facts. After a two-year qualitative study of students with mild disabilities in hands-on science classes, we concluded that students greatly enjoyed the science activities and appeared to benefit substantially from the opportunity to interact directly with scientific materials (Scruggs \& Mastropieri, 1994a). Off-task or inappropriate behavior was rarely observed to be a problem (see also Cawley, Hayden, Cade, \& BakerKrooczynski, 2002). While we did observe that students with mild mental retardation displayed some difficulty with some aspects of these tasks, such as independent reasoning, attending to relevant stimuli, and remembering critical verbal information (Scruggs \& Mastropieri, 1995), teachers were able to adjust their instruction to accommodate these issues. Further, we also observed that some students with mental retardation appeared to exhibit preconceptions about scientific concepts that were years below those of their age peers. For example, some 3rd or 4th grade students with mental retardation believed that air is found in wind or drafts, and is not typically found indoors. For example, "Martin," when asked where air is found, replied to the interviewer:

Martin: Outside
Int.: We find it outside. Does it do anything for you?
Martin: It gives you goosebumps.
Int.: Do you think there is air in this cup?
Martin: No.
Int.: What do we breathe?
Martin: No [puts his ear to the cup on the scale].
Int.: $\quad$ You tried to listen to it? There wasn't any air in
there?
Martin: This was the cold (Scruggs, Mastropieri,
$\quad$ \& Wolfe, 1995, p. 228).

Preconceptions like these are commonly found in normally achieving preschoolers (Driver, Asoko, Leach, Mortimer, \& Scott, 1994); therefore, teachers should carefully consider students' prior understanding of scientific phenomena when starting a new unit of study.

Although science can be an interesting and enriching area of study, students with disabilities may encounter some learning difficulties regardless of how the content is presented. For this reason, it is important to examine research in a number of aspects of science learning that has addressed different ways of facilitating many different types of science learning (for a discussion of the debate on constructed vs. instructed science learning, see Scruggs \& Mastropieri, 2007).

\section{Instructional Practices for Promoting Science Learning}

\section{Mnemonic Instruction}

Any approach to science requires learning unfamiliar and sometimes abstract vocabulary. The sooner the most important vocabulary is assimilated, the more time can be devoted 
to deepening conceptual understandings. One method for promoting high levels of recall of unfamiliar vocabulary and terminology is the keyword method (Atkinson, 1975). Using the keyword method, a concrete, acoustically similar keyword is created as a proxy for the unfamiliar vocabulary word. For example, to promote recall of the unfamiliar scientific term ranidae, which refers to the family of common frogs, a familiar, acoustically similar keyword is created to represent the unfamiliar word. In the present instance, "rain" (or, "rainy day") would be a good keyword for ranidae, since it sounds like the first part of ranidae and can be easily represented in a picture. After this, an interactive picture is created in which the keyword (rain) is shown interacting with the definition (frog), in this case, a picture of a frog sitting in the rain. After studying the picture and keyword links, and when asked the meaning of ranidae, learners first think of the keyword (rain), think of the picture with the rain in it (frog in the rain), and retrieve the correct answer, frogs (Mastropieri \& Scruggs, 2010, chapter 10). The keyword method and its variants (e.g., the pegword method for numbered or ordered information, using rhyming proxies for numbers) have been extensively studied with students with mild disabilities. They have been found to be very effective for enhancing science content information in a wide variety of domains and in other areas such as English and foreign language vocabulary (e.g., Mastropieri, Scruggs, \& Fulk, 1990) and social studies (e.g., Mastropieri \& Scruggs, 1988). In science, mnemonic strategies have been employed to improve recall in the subject areas of paleontology (Veit, Scruggs, \& Mastropieri, 1986), geology (Mastropieri, Scruggs, \& Levin, 1985; 1986; 1987; Scruggs, Mastropieri, Levin, \& Gaffney, 1985), chemistry (Mastropieri, Scruggs, \& Graetz, 2005), and life sciences (Mastropieri, Emerick, \& Scruggs, 1988; Scruggs \& Mastropieri, 1992a). These results were seen to maintain over several days (Veit et al., 1986; Mastropieri, Emerick, \& Scruggs) or weeks of classroom instruction (Scruggs \& Mastropieri). In the latter investigations, mnemonic instruction was integrated entirely within units of paleontology, life science (including vertebrate and invertebrate animals), and geology. It has also been seen that students with learning disabilities can be trained to generate their own mnemonic strategies, although somewhat less efficiently than teachers or researchers (Fulk, Mastropieri, \& Scruggs, 1992; King-Sears, Mercer, \& Sindelar, 1992).

In research synthesis of mnemonic strategy research in special education, Scruggs and Mastropieri (2000) reported that, in the area of science, 13 studies yielded a mean effect size of $1.59(S D=.93)$; in other words, these strategies were extremely effective in promoting memory for science content. Further, these results were found to be robust when implemented by different researchers (e.g., Bulgren, Schumaker, \&
Deshler, 1994). This research synthesis has itself recently been updated and replicated, with very similar findings (Wolgemuth, Cobb, \& Alwell, 2008). Clearly, mnemonic strategies have been demonstrated to be highly effective for promoting recall of verbally based information in science as well as other academic content areas. And although rote recall and memorizing of content information are frequently regarded with disdain as "lower level" objectives inferior in stature to "higher order" thinking-type objectives, the critical importance of content recall for school success can hardly be underestimated (Scruggs \& Mastropieri, 2007). Nevertheless, there is certainly much more to science learning than recall of verbal information, and other strategies have been demonstrated to be effective in promoting these other areas of learning.

\section{Text Comprehension and Organization}

Most science classes require at least some independent study from science texts, and these requirements can provide some difficulties for students with disabilities. Strategies to enhance comprehension of expository text, such as summarization strategies (where students are asked to restate main ideas or provide summary statements in their own words) have been effectively implemented with students with learning disabilities studying science text (Nelson, Smith, \& Dodd, 1992). Bakken, Mastropieri, and Scruggs, (1997) taught students with learning disabilities to evaluate expository text structure and vary study strategies accordingly. Students were taught to differentiate main idea, list, and sequence text structures. Main idea structure provides a central idea in a given paragraph (e.g., erosion, osmosis) and supporting statements. List structure provides a number of examples of a phenomenon (e.g., examples of arachnids, or types of mountains); while order structure provides a number of elements in a fixed order (e.g., steps in the process of auditory reception, planets in order from the sun, order of geologic periods). This was a particularly complicated strategy, requiring several days of implementation. However, the results suggested that students trained to use this strategy greatly outperformed peers trained to use only effective summary strategies as well as those in a free study condition.

In addition, text enhancements have been employed to provide aids to comprehension with such features as graphic representations and framed outlines (e.g., Bergerud, Lovitt, \& Horton, 1988; Lovitt, Rudsit, Jenkins, Pious, \& Benedetti, 1986) and text-embedded mnemonic illustrations (Mastropieri, Scruggs, \& Levin, 1987). In a recent meta-analysis of content area learning for students with disabilities, Scruggs, Mastropieri, Berkeley, and Graetz (in press) reported that spatial or graphic organizers, such as the "Concept Comparison Routine" to teach students with learning 
disabilities information about tropical diseases in high school science classes (Bulgren, Lenz, Schumaker, Deshler, \& Marquis, 2002), were highly effective (see also Bulgren, Schumaker, \& Deshler, 1998; Darch \& Eaves, 1986).

\section{Hands-on Science Curriculum}

Given the characteristics of students with mild disabilities, particularly in the areas of literacy deficits and ability to benefit from concrete representations, it would make sense that these students would benefit from a hands-on science curriculum, where students learn by doing rather than reading. In fact, research to date has demonstrated this to be the case. Scruggs, Mastropieri, Bakken, and Brigham (1993) implemented a hands-on activities approach to learning units of rocks and minerals and of electricity and magnetism in eighth-grade special education classes of students with learning disabilities and behavioral disorders, and they compared learning outcomes with those of the students studying the same content from teacher lecture and textbook presentations. For example, while one group built and experimented with electromagnets and telegraphs, the other group learned the same content read from text and completed worksheets. It was found, as predicted, that students taught with hands-on science materials performed substantially higher on posttests. These positive outcomes have also been reported in similar research (Bay, Staver, Bryan, \& Hale, 1992; Dalton, Morocco, \& Tivnan, 1997; McCarthy, 2005). However, hands-on instruction by itself can not be regarded as a panacea to science learning; Brigham, Scruggs, and Mastropieri (1992) implemented hands-on units on atmospheric and earth science across special education science classes and reported that, even when hands-on materials were employed, teacher enthusiasm was still very important in increasing academic achievement and on-task behavior.

Mastropieri and colleagues (1998) implemented a handson science unit in the area of ecosystems and compared learning outcomes with textbook approaches in three fourthgrade classrooms. The inclusive, hands-on classroom included students with physical disabilities, emotional disabilities, learning disabilities, and intellectual disabilities. Students worked in cooperative groups to create ecosystems; experiment on them with fertilizer, "acid rain" (diluted vinegar), and road salt; and record and describe results. The students in the comparison classes studied the same content from textbooks. Not only did the students in the hands-on condition outperform textbook condition students (even on the textbook-based test), the seven students with a variety of disabilities in the hands-on condition outperformed normally-achieving students in the textbook condition. Further, within the experimental classroom, these students performed within the average range of all students in the classroom. The difference in the depth of understanding can be described by different responses to the question, "Tell me everything you can about an ecosystem." One typical response from a normally-achieving student from a textbook condition class was, "Living and nonliving things that surround and affect each other" (p. 174). In contrast, a student with learning disabilities in the hands-on classroom responded,

It has living things and nonliving things. It has consumers, decomposers, producers, predators, prey, parasites, and hosts. It has water, soil, air, and light. Some of the living things get eaten. The living and nonliving things in an ecosystem help each other. (Mastropieri et al., 1998, p. 174)

Similarly, Palincsar, Magnusson, Collins, and Cutter (2001) studied inclusive upper-elementary science classes studying floating and sinking, and properties of light, over a 2 -year period. These researchers reported substantial overall learning gains when they implemented appropriately adapted hands-on instruction for students with learning disabilities. The adaptations included monitoring and facilitating student thinking through rehearsing and mini-conferencing, supporting print literacy through vocabulary enhancement and support for written lab reports, and improving small-group functioning with monitoring and feedback.

\section{Inductive Thinking of Students With Mild Disabilities}

Given the characteristics of learners with mild disabilities, it could be predicted that supported activities with concrete materials would improve learning outcomes for this population. However, such approaches are often accompanied by inquiry methods, in which students are encouraged to reason independently about scientific phenomena and derive their own conclusions. Since independent reasoning is not generally regarded to be a relative strength of students with mild disabilities (e.g., Ellis, 1993), the benefit of such methods could be questioned.

Two experiments were conducted to determine whether students with mild disabilities are able to construct scientific principles through prompting and questioning. Mastropieri, Scruggs, and Butcher (1997) provided an interactive demonstration of pendulum movement to normally achieving students, as well as students with learning disabilities and mental retardation. After observing the swing rate of pendulums of different lengths, students were invited to create a general rule for pendulum movement (i.e., the longer the string, the slower the pendulum swings). If students did not immediately provide the correct explanation, a series of more explicit prompts were provided to elicit the general rule. Under these conditions, normally achieving students drew the correct conclusions either immediately or after only a small number of prompts, and students with learning disabilities performed only slightly less well. However, 
none of the students with mental retardation ever drew the correct conclusion until it was provided explicitly by the experimenter. The students with learning disabilities and students with mental retardation both experienced some difficulty transferring this knowledge to a task involving the motion of a pendulum clock. Normally achieving students, on the other hand, had little difficulty with this transfer task.

Similarly, Mastropieri, Scruggs, Boon, and Carter (2001) examined inductive thinking in the context of density and buoyancy concepts with normally achieving students and students with mild disabilities. They reported that psychometric IQ was a strong predictor of students' ability to draw relevant inductive conclusions about density and buoyancy. Transfer of knowledge to related domains (in this case, oil spills) again posed greater difficulties for students with mild disabilities than for normally achieving students. The results of these experiments do not mean that students with mild disabilities cannot construct scientific knowledge under any circumstances; however, it does appear they are less skilled in this area than normally-achieving peers.

\section{Coached Elaborations and Guided Inquiry}

Although the performance of students with disabilities on inductive learning tasks was lower than that of normallyachieving students, they may nonetheless benefit from highly structured inquiry learning. In a series of experiments, Scruggs, Mastropieri, and colleagues (Scruggs, Mastropieri, \& Sullivan, 1994; Scruggs, Mastropieri, Sullivan, \& Hesser, 1993; Sullivan, Mastropieri, \& Scruggs, 1995) evaluated the effectiveness of highly structured inquiry methods on student learning. Elementary grade students were taught information about different animals and explanations for that information under three conditions. The first condition provided direct practice on the content, using dialogue similar to the following:

\begin{tabular}{|c|c|}
\hline Experimenter: & $\begin{array}{l}\text { The anteater has long claws on its front } \\
\text { feet. What does the anteater have? }\end{array}$ \\
\hline Student: & Long claws on its front feet. \\
\hline Experimenter: & Long claws on its front feet. Good. \\
\hline
\end{tabular}

In the second condition, students were directly taught both the fact and the explanation for the fact, using dialogue similar to the following:

Experimenter: The anteater has long claws on its front feet, to help it dig for ants. What does the anteater have?

Student: It has long claws on its front feet.

Experimenter: Yes, the anteater has long claws on its front feet. Good. And why does it have these long claws?

Student: To help it dig for ants.

Experimenter: To help it dig for ants. Good.
In the experimental (coached elaborations) conditions, we asked learners to "construct" the explanation for themselves, through explicit questioning provided by the experimenter, such as the following:

$\begin{array}{ll}\text { Experimenter: } & \begin{array}{l}\text { The anteater has long claws on its front } \\ \text { feet. Why does it make sense that the } \\ \text { anteater would have long claws on its } \\ \text { front feet? }\end{array} \\ \text { Student: } & \text { I don't know. } \\ \text { Experimenter: } & \text { Well, let's think about it together. } \\ & \text { What does the anteater eat? } \\ \text { Student: } & \text { Ants? } \\ \text { Experimenter: } & \text { Ants, good. Anteaters eat ants. } \\ \text { Student: } & \text { They live in the ground, in holes. } \\ \text { Experimenter: } & \begin{array}{l}\text { In holes in the ground. So why would it } \\ \text { make sense that the anteater would have } \\ \text { long claws on its front feet? }\end{array} \\ \text { Student: } & \text { Oh-to help it dig for ants. } \\ \text { Experimenter: } & \text { Yes, exactly, to help it dig for ants. Good. }\end{array}$

Whatever the condition, all students spent the same amount of time interacting with the experimenter learning the target content. After the learning task and a "filler" interval students were asked to recall the fact about each animal (e.g., long claws) and the explanation for that fact (to dig for ants). In the first condition, students were asked for the explanation as a test of how much students could be expected to provide in these cases without any input from the experimenter. In all three experiments, the students remembered the facts, as well as the explanations for those facts, best in the coached elaborations condition. Recall was low in the direct practice condition, where they independently constructed few if any explanations. The most interesting finding was that coached elaboration students recalled explanations better than students who were directly provided this same information. It is interesting because students in that condition were never explicitly told the explanation for the facts; rather, the students derived the explanations themselves solely from the questioning of the experimenter. In this condition, however, questioning was very explicit and targeted directly to student construction of the answer. In a follow-up investigation, Mastropieri and colleagues (1996) taught students to ask themselves, after reading each fact, "why does that make sense?" (p. 5) In this case, students were only partly successful in implementing this strategy independently. Overall, it can be concluded that students with mild disabilities can benefit from guided inquiry and higher-order questioning, but instruction using these methods must be highly structured and supportive.

Although the coached elaborations studies were conducted in laboratory-like settings, similar supported 
questioning techniques have been observed in classroom settings, such as the following from a special education classroom studying the effects of capillary action:

$\begin{array}{ll}\text { T1: } & \text {.. what do you think happened? I have a flower } \\ & \text { in blue water and a flower in green water, a } \\ & \text { white flower, right? Ken, what is the color of } \\ \text { this flower? } & \text { Blue. } \\ \text { Ken: } & \text { White. } \\ \text { Sam: } & \text { White and blue. Julie, what color is this flower? } \\ \text { T1: } & \text { Green. } \\ \text { Julie: } & \text { White and green. How did I get the colors } \\ \text { T1: } & \text { There? How did I get the colors there, Shawn? } \\ \text { Shawn: } & \text { That's from a stain in there like... } \\ \text { T1: } & \text { blue get here? } \\ \text { Ken: } & \text {.. Oh, you watered it with food coloring. } \\ \text { T1: } & \text { But I didn't put any up here, did I? } \\ \text { Ken: } & \text { You put it in the dirt. } \\ \text { T1: } & \text { But there's no dirt. } \\ \text { Ken: } & \text { Oh. } \\ \text { T1: } & \text { How did it get from there to here? } \\ \text { Students: } & \text { I know. I know. It raised. } \\ \text { T1: } & \text { OK, Jimmy, what do you think? } \\ \text {-Jimmy: } & \text { It went all the way up to here. } \\ \text { T1: } & \text { Went all the way through water? The what, } \\ \text { Mary: } & \text { Mary? } \\ \text { T1: } & \text { The stem. It went all the way through the stem, } \\ & \text { (Scruggs \& Mastropieri, 1995, p. 264). }\end{array}$

As another example, Mastropieri and colleagues (1998) reported the following dialogue between teacher and student, as the teacher attempted to promote more general understanding of relevant concepts in life science:

$\mathrm{T}$ : $\quad$ So what are we finding? Jonathan, did you hear that? The acid rain groups had 4.5 or 5 in their water. So what's that telling you?

S1: $\quad$ That it's more polluted.

S2: Oh, the acid went through.

T: The acid went through. The acid went through [from the terrarium] down to the aquarium. So does it make sense that that little guy [guppie] is being affected?

S1: Yes.

T: What is an ecosystem? Tell me the definition of an ecosystem [student].

S1: A place where living and nonliving affect and depend on each other.

T: $\quad$ They affect each other and they depend on each other, living and nonliving things. Is this water, this acid in the water affecting those fish?
Ss: $\quad$ Yes
T: $\quad$ Yes, isn't that amazing! Okay, you guys did a fantastic job! Great job! (videotape transcript, 12/12) (pp. 171-172)

Similarly, Palincsar, Collins, Marano, and Magnusson (2000) reported on the effectiveness of guided inquiry and hands-on experiences in promoting the conceptual understanding of students with learning disabilities studying concepts of buoyancy.

\section{What is Important for Effective Inclusive Science Learning?}

Over a period of two years, Scruggs and Mastropieri (1994b) studied outstanding inclusive science classrooms, in a school district well known for excellence in science learning. These elementary classrooms contained students with a variety of disabilities, including visual impairments, physical disabilities, hearing impairments, learning disabilities, and autism. From an analysis of the data collected from these observations, interviews, and curriculum materials and classroom products, Scruggs and Mastropieri concluded that seven variables were highly significant in promoting effective inclusive education in science, including the following:

1. An open, accepting classroom environment

2. Administrative support for inclusion

3. General effective teaching skills on the part of the general education teacher

4. Special education support, in the form of consultation or direct assistance

5. Peer mediation, in the form of classroom assistance or cooperative learning

6. Appropriate curriculum (supporting a hands-on approach to science learning)

7. Teaching skills specific to particular disability or need areas (Scruggs \& Mastropieri, 1994b)

Many of these same variables were also observed and reported by Mastropieri and colleagues (1998), and Mastropieri, Scruggs, and Bohs, (1994).

\section{Differentiated Curriculum Enhancements}

Many of today's secondary science classrooms place great emphasis on high stakes testing, typically requiring high levels of verbal recall of broad, shallow content knowledge. Maximizing engagement and practice on appropriate levels of content learning in situations where there is considerable diversity in learning abilities is a significant problem. One possible approach for maximizing learning is applications of classwide peer tutoring, similar to that used by Doug and Lynn Fuchs and colleagues (e.g., Fuchs, Fuchs, \& Kazdan, 1999; Mathes, Howard, Allen, \& Fuchs, 1998). 
Peer tutoring in this content could be expected to increase practice and engagement with classroom content. Although all students in these classrooms could not be expected to perform similarly on content with the same level of difficulty, it may be important in secondary classes to avoid the stigma of some students being provided classroom materials of obviously lower difficulty level. Mastropieri, Scruggs and colleagues attempted to address this issue by creating classroom materials of different difficulty levels which could be employed differentially in terms of student need but nonetheless were the same overall for all tutoring pairs. Mastropieri, Scruggs, and Graetz (2005) implemented classwide peer tutoring in high school chemistry classes, using "differentiated curriculum enhancements." In this case, the tutoring materials, which were based on high stakes testing requirements, incorporated both mnemonic and elaborative materials. These strategies were developed so that they could be used only if needed by the tutoring pairs. For example, students tutored each other on such content as thermic reactions, enthalpy, molarity, the Periodic table, valence electrons, and covalent bonding. If students demonstrated adequate recall, tutors moved directly on to elaborative questioning of the content (e.g., "can you give me an example of / tell me more about ...?"). If students did not recall the information, an elaborative strategy was displayed (e.g., a picture of a thermos of hot coffee to remind the students that thermic represented heat). This model of instruction was referred to as differentiated curriculum enhancements, since differentiated instruction was provided, depending on needs of individual students. After 9 weeks of tutoring, Mastropieri and colleagues (2005) reported that experimental condition outperformed comparison students, and that students with learning disabilities appeared to gain more $(42.5 \%$ more) than normally achieving students (16.1\%) - although this interaction was not statistically significant.

In another investigation, Mastropieri and colleagues (2006) conducted similar research in middle school classes, in which the differentiated curriculum enhancements were employed somewhat differently. In this case, classwide tutoring pairs went through a number of game-like activities (such as "Concentration," "Vocabulary Challenge," "Liquid Measurement," and "Jeopardy"), in sequence of difficulty levels. Each activity was presented as levels 1 through 3 , in order of difficulty, and all tutoring pairs were expected to proceed consecutively from level 1 to level 3. Level 1 activities required the simplest response (e.g., identification of the correct answer from an array); level 2 activities required more difficult responses (e.g., production responses, with prompts when needed); and level 3 activities required the most difficult responses (e.g., unprompted production responses). Instruction was differentiated, then, to the extent that individual tutoring pairs could work on their appropriate difficulty level as long as it took to master the content and move to the next difficulty level. The intervention was conducted in 13 science classrooms over a period of 14 weeks. It was reported that students in the experimental classrooms outperformed control condition students on both classroom unit tests and end-of-year statewide high stakes tests, with students with and without disabilities benefiting similarly. This model of science learning in inclusive classrooms has more recently been replicated by McDuffie, Mastropieri, and Scruggs (2007) in the area of middle school genetics, and by Simpkins, Mastropieri, and Scruggs (in press) in the area of Earth and space science, and light and sound units in elementary inclusive classrooms. The results of all experiments have suggested that classwide peer tutoring with materials that address the differential learning needs of all students can be very effective in promoting learning in inclusive classrooms by students with and without disabilities.

\section{Discussion}

Research in science education for students with disabilities over the past few decades has added substantially to the knowledge base in this area. It is clear that there are multiple objectives to science learning, a wide variety of topics to be undertaken, and some very different approaches to curriculum and instruction in science. Nevertheless, it is necessary for special education as a field to develop and validate instructional practices in all relevant areas. Much work to date in these areas has been accomplished, including memory-enhancing strategies, strategies for organizing and comprehending science text, strategies for promoting inquirybased learning, hands-on science activities, and strategies for promoting learning of broad areas of science in inclusive classroom contexts, as preparation for high stakes testing. More research in all of these areas could provide important information on how learning could be maximized for students with special needs and how these students can become a greater part of the scientific learning community as they are able to enhance their own lives with their greater understanding of the universe and our place in it.

\section{SOCIAL STUDIES EDUCATION}

\section{Social Studies Education and Special Education}

According to the National Council for the Social Studies (NCCS), the preeminent professional organization for social studies educators:

Social studies is the integrated study of the social sciences and humanities to promote civic competence. Within the school program, social studies provides coordinated, systematic study drawing upon such disciplines as anthropology, 
archaeology, economics, geography, history, law, philosophy, political science, psychology, religion, and sociology, as well as appropriate content from the humanities, mathematics, and natural sciences. The primary purpose of social studies is to help young people develop the ability to make informed and reasoned decisions for the public good as citizens of a culturally diverse, democratic society in an interdependent world. (NCSS, 2008)

The NCCS definition highlights some of the key features of social studies that make it a unique subject in today's curriculum. First, social studies instruction draws content and ideas from disciplines that vary in their substance, goals, and methods of inquiry. As a consequence, social studies offers a rich arena in which students can do more than learn facts-they can learn and apply problem-solving skills, examine issues and events from multiple perspectives, engage in authentic literacy activities, and be apprenticed into different means of inquiry and habits of mind (NCCS, 2008). Second, social studies instruction has a publicly recognized social goal - to prepare students for participation in the decisions and actions that can improve the society in which they live. Third, the relevance of many social studies topics to everyday life is perhaps more direct than is the case in other subjects, facilitating the potential application and generalization of social studies learning.

In the $\mathrm{K}-8$ curriculum, the strands of social studies, history, geography, civics, and economics are often woven together in each grade-level curriculum, with history receiving more attention than other domains. When students reach high school, social studies takes on more of a disciplinary flavor as students take separate courses such as American History, World History, European History, United States Government, or Economics.

Social studies has not received the attention afforded to mathematics, science, and English/language arts in the most recent wave of educational reforms (Bailey, Shaw \& Hollifield, 2006; Wineburg \& Grossman, 2001), nor has it been a priority for special educators (Lintner \& Schweder, 2008). Although the vast majority of states have developed content-area standards in social studies and test social studies achievement on a regular basis, progress in social studies is not measured at the federal level, and schools are not held accountable for progress in social studies as they are in mathematics, English/language arts, and science. With less scrutiny given to student performance in social studies, it has received less funding, research, and curricular and professional development than other subject areas. This lack of attention seems unfortunate, given the learning opportunities afforded by social studies. However, one also could argue that social studies instruction in today's schools is less constrained by accountability concerns and, as such, may offer teachers the flexibility that stimulates innovation and greater tolerance of individual differences-ingredients that can promote fuller and more successful inclusion of students with disabilities.

\section{Social Studies Curriculum and Characteristics of the Learner}

As discussed earlier, instruction is best viewed in the context of both curricular and learner characteristics (Mastropieri \& Scruggs, 2010; Scruggs \& Mastropieri, 1992b). This consideration is as valid for social studies as it is for science. In social studies, the textbook, to a great degree, shapes and constrains instruction and interacts with the literacy difficulties that are typical among students with disabilities. Furthermore, social studies content makes considerable demands on the cognitive capabilities of students. We discuss each of these issues below.

\section{The Role of the Textbook in Social Studies Instruction}

The textbook remains the primary vehicle for instruction in social studies classes (Harniss, Dickson, Kinder, \& Hollenback, 2001; Meyers \& Savage, 2005). As discussed earlier, textbooks are often ill structured and inconsiderate (Armbruster \& Anderson, 1984; Bean, Zigmond, \& Hartman, 1994; Beck \& McKeown, 1991; Brophy, 1990; Paxton, 1999). Readability levels often very widely. In our analysis of two commercial social studies texts, examination of 30 random 500-word passages per book revealed readability levels between 8.3 and 12.6 (Socol, Okolo, \& Feyen, in preparation). Textbooks are rarely constructed in ways that help readers make sense of information that is covered in a superficial manner, "a mile wide and an inch deep" (Schmidt, Houang \& Cogan, 2002, p. 3). These limitations are particularly problematic when the goal of instruction is integration of different disciplines, as is the case with social studies.

The study of history is particularly limited by textbookbased instruction. Historical understanding demands that learners have access to the multiple perspectives and sources that speak to a historical event or issue. Historians must consider divergent points of view or their accounts of history will be incomplete and their conclusions will be misleading. And because a full set of data upon which to base conclusions about history is rarely available, historical understanding ultimately requires interpretation (Paxton, 1999; VanSledright, 2002). However, textbooks too often portray history as a list of dates, set of facts, and list of characters. As Spoehr and Spoehr (1994) note, "history is about facts in much the same way that reading is about the alphabet" (p. 27). The process of inquiry that goes into constructing history - the coordination of perspectives, the interpretation of sources, the principled reasoning about uncertainties-is obscured in textbook presentations, and 
"the way things are told is simply the way things were" (Wineburg, 2001, p. 12).

\section{Cognitive Challenges of Social Studies Learning}

Perhaps more than other school subjects, social studies requires students to contemplate abstract concepts and principles that include economic systems, government, culture, civic roles and responsibilities, geography, and change and continuity, to name a few. Consider, for example, what is entailed in attempting to understand events and people from the distant past-the core of history instruction. Wineburg (2001) speaks of historical thinking as an "unnatural act" and Lowenthal (2000, p. 76) cautions us that, "the past was not only weirder than we realize; it was weirder than we can imagine" (p. 76). Most educated adults in the United States are unable to grasp the historical basis for conflict in the Middle East, for example, or to evaluate the different responses the government might make to an economic recession.

Students come to the study of these concepts with limited experience upon which to build knowledge of basic principles in the social studies disciplines. As one social studies teacher in our studies described her middle schoolers, "they have 10-year old minds" (Okolo, Ferretti, \& MacArthur, 2002). The cognitive and socio-emotional development of novice learners constrains their ability to differentiate time and to develop historical empathy (Brophy \& Alleman, 2002; 2003, Okolo et al., 2002). Understanding the perspective of people who are very different than oneself requires more than empathy, however. Students need a rich store of background knowledge about people, events, and times before they can be expected to see the world through someone else's eyes.

On the other hand, students also come to school with an everyday knowledge of social studies topics and often think they understand more than they do (Bain, 2006; Fertig, 2008). A viewing of the popular movie Forrest Gump leads to the belief that a student is informed about the Vietnam War (Wineburg, 2000). Or, dinner table conversation about immigration and economic policies may lead a student to conclude there is only one desirable federal response (MacArthur, Ferretti, \& Okolo, 2002). As in science, these everyday experiences create powerful misconceptions and predispositions that, unless addressed directly, can severely limit the growth of students' understanding (Brophy \& Alleman, 2002: Ferretti, MacArthur, \& Okolo, 2007). These issues are perhaps best summarized in a middle school teacher's description of her attempts to teach students about the development of transportation systems in the mid-1800s:

It's difficult for them to appreciate the fact that building the railroad system started with laying the track, the enormous amount of work and labor involved in this, the dangers of the job. Kids tend to think of the world back then as it is today - you just go out to the station and get on the train. I spent a lot of time with this group and, even then, it was tough to get the kids to see that there were only a few railroad lines, that they were restricted to major cities, that people anywhere in the country couldn't travel on trains wherever they wanted to go. (Okolo et al., 2002, p. 301)

Thus, teachers should keep in mind that social studies instruction presents considerable challenges to children and young adults. The challenges are even greater for students with disabilities, whose cognitive development and background knowledge are often more constrained than that of peers without disabilities.

\section{Instructional Practices for Promoting Social Studies Learning}

Social studies instruction can be conceptualized as operating on four different levels. At the most basic level, social studies entails factual learning, or the development of declarative knowledge about specialized vocabulary, important people, key events, and dates. Learning at this level also involves making associations among facts (e.g., Confederate-Union-Civil War-1860s). In social studies, fact-based learning is often separated into disciplines, with students learning facts about the monetary system, for example, in a portion of the social studies curriculum that deals with economics, whereas facts about the spread of religions across Europe are taught in the world history portion of the curriculum. Thus, factual learning is perhaps the least interdisciplinary aspect of typical social studies instruction.

Fact-based learning is not sufficient for developing students' understanding of social studies and the disciplines it represents. Students also need to develop an understanding of social studies concepts, such as migration, free trade, or capitalism. Conceptual learning results in an understanding of the key features of objects, events, or ideas, and what differentiates one concept from another (Bruner, Goodnow, \& Austin, 1967). Conceptual learning offers more opportunities for the integration of ideas across disciplines, time periods, and perspectives.

Procedural learning refers to knowledge of how to perform a task or the processes used to carry out a task. Many aspects of social studies learning require procedural knowledge. For example, determining the absolute location of a country, computing how many members of the United States House of Representatives should be allotted to a particular state, or knowing the process of writing a persuasive essay all require procedural knowledge in addition to factual and conceptual knowledge. Procedural knowledge also guides investigation or inquiry in the social studies. The process for corroborating sources in historical inquiry, for example, requires procedural knowledge. 
Finally, an important goal of social studies instruction is investigative learning, in which students engage in the heart of disciplinary activities, such as historical inquiry or geographic exploration. Investigative learning cements factual, conceptual, and procedural learning across the social studies disciplines and helps students develop interconnected knowledge, problem solving skills, and application of knowledge to real life situations.

This four-part conceptualization of social studies learning and instruction should not imply that one level of learning is more important than others. Factual knowledge is an essential base upon which to build an understanding of concepts, and investigation would not be very productive without the foundation of facts, concepts, and procedures. In the remainder of this section, we explore ideas for teaching social studies at each of these levels.

\section{Factual Learning}

Vocabulary knowledge, as discussed above, is a critical element in a subject that has its own set of discipline-specific language and principles. In fact, special education researchers have shown that vocabulary matching tests, used as curriculum-based measures, are highly correlated with performance on knowledge tests, course grades, and scores on a standardized test of social studies (Espin, Busch, Shin, \& Kruschwitz, 2001).

However, teaching much of the social studies vocabulary at a conceptual level (discussed later) is both unrealistic and unnecessary. Teachers will have to make choices about which words to teach at a factual level - through associating a word with its definition (e.g., absolute location, excise tax) and which words to teach in a more elaborated manner (e.g., Diaspora, citizenship). Terms that are most central to a unit of instruction or represent key concepts or "big ideas" in a domain are best taught at a conceptual level.

The "look it up, write the definition, write it in a sentence" method often used for teaching vocabulary as a set of associations is not very successful (Ellis, 2002). More effective practices for teaching vocabulary associations include the following (Bryant, Goodwin, Bryant, \& Higgins, 2003; Carlisle, 1993b; Ellis, 2002; Jitendra, Edwards, Sacks, \& Jacobson, 2004; McKeown \& Beck, 1988):

- Preview vocabulary with students prior to reading, lecture, or discussion.

- Create study aids such as notecards.

- Link new vocabulary to familiar ideas and experiences.

- Practice to-be-learned words in small sets of 3-5 until mastery.

- Use short practice sessions, spread over time, rather than lengthier, "cram" study sessions.
- Avoid teaching easily confusable words in the same set.

- Provide frequent and systematic review, interspersed with practice on new words.

\section{Learning From Lectures and Study Guides}

Lectures are a common feature of social studies instruction. Not surprisingly, research has shown that students with reading and language disabilities learn less from lectures, as measured by comprehension of content, than do their peers (Ward-Lonergan, Liles, \& Anderson, 1999). Instructional practices that improve the amount of information students learn and retain from lectures include review of prior information, guided notetaking, lecture outlines, and frequent pauses to ask questions and summarize information (Hudson, 1996; 1997). Study guides, which make explicit the information that students are expected to learn for tests or other evaluation activities, also effectively improve the performance of students with disabilities in social studies classes (Higgins, Boone, \& Lovitt, 1996; Horton \& Lovitt, 1989).

\section{Conceptual Learning}

\section{Teaching Vocabulary}

As discussed earlier, teachers should reserve key vocabulary words - those that represent important ideas or will be repeated across topics-for more extensive instruction. Vocabulary instruction to develop conceptual learning and understanding is more time- and labor-intensive than teaching vocabulary at the factual level, but it pays dividends in facilitating students' text comprehension and generalization of word meanings across contexts (McKeown \& Beck, 1988). Students' conceptual understanding is best attained by teaching words in more depth through elaboration techniques such as mnemonic instruction (discussed earlier). Teaching words in context and demonstrating and discussing different situations in which they occur, including those outside of the social studies, extends students' understanding of the nuances of word meaning and helps them generalize their vocabulary understanding to novel material.

\section{Organizing Content}

Research into instructional practices that support learning for students with disabilities clearly shows that organizing information around big ideas benefits students' conceptual learning (Marchand-Martella, Slocum, \& Martella, 2004). This practice is particularly relevant for social studies. With its ostensible focus on the integration of information from different disciplines, social studies runs a greater risk than other subjects of appearing to students as a fragmented set of loosely related ideas that defies their understanding and retention of information. 
One strand of research has investigated the impact of rewriting social studies texts to conform to research-based instructional principles. A more conceptually coherent text improves comprehension (Crawford, \& Carnine, 2000; Twyman \& Tindal, 2006) as does making events more dynamic, including conversational devices from oral language and making explicit connections between reader and text (Beck, McKeown, \& Worthy, 1995). We will not explore ways to rewrite texts here, however, based on the assumption that such activities are too time-consuming and fraught with other difficulties, such as copyright restrictions. Rather, we will focus on ideas for organizing classroombased instruction.

Kinder and Bursuck (1991) advocated a sameness analysis of the social studies curriculum, in which common frameworks, such as problem-solution-effect, can be applied across multiple topics and units. These researchers worked with three classes of students with behavior disorders to implement an intervention that included content and vocabulary instruction, problem-solution-effect analysis of the text through group discussion, notetaking, time lining, and reciprocal questioning. The intervention resulted in improved performance on a test taken from the textbook (Kinder \& Bursuck, 1993).

Ferretti and colleagues (Ferretti, MacArthur, \& Okolo, 2001; 2007; MacArthur et al., 2002) developed several frameworks around which to organize historical content. A migration and conflict schema was used as a foundation for teaching about several different immigrant groups during the early $20^{\text {th }}$ century and in a unit about westward migration in the United States. We speculated that this framework would guide students' analysis of conditions that serve as a catalyst for movement within or across a country and the factors that cause conflict when one group moves into an area occupied by another group. We also taught a ways of life framework to compare the perspectives of two different groups of people in terms of political, social, economic, governmental, and religious beliefs. The ways of life framework was designed to assist students in systematically determining similarities and differences in two or more groups' ways of life, thus helping students pinpoint reasons for conflicts. Middle school students with mild disabilities were able to apply the migration and conflict schema to novel situations but were less adept at using the ways of life framework (MacArthur et al.).

Researchers at the University of Kansas have designed sets of teaching practices, called Content Enhancement Routines (CERs) that have been used in a variety of content-area classes, including social studies (Bulgren, Deshler, \& Lenz, 2007; Deshler et al., 2001). CERs are built around the types of difficulties commonly experienced by students with disabilities in general education classes, including background knowledge, coordinating multiple sources of information, reasoning, synthesizing and summarizing, and generalizing. CERs include a variety of activities that encourage student engagement and interaction, make use of graphic organizers and other ways to display and consolidate information, and teach strategic and metacognitive approaches to learning. Bulgren and colleagues (2007) illustrate the use of CERs to teach a unit on the Civil War by first organizing information into knowledge structures, facts, critical questions, and connections among ideas. Concepts that are central to the unit are identified and analyzed in more depth, and they are taught through devices that help students link new concepts to prior knowledge and synthesize what they have learned. Graphic organizers help students develop their understanding of the relationship among ideas through comparison and cause-effect routines. Results of this study included positive academic outcomes, including quality of notetaking and performance on cause-effect activities. Furthermore, students expressed more confidence in their use of strategies and the accuracy of their performance after participating in classes using CERs (Bulgren, Deshler, \& Schumaker, 1998).

Cultural universals are another set of ideas for organizing social studies instruction to promote conceptual understanding, particularly in elementary school classrooms (Brophy \& Alleman, 2006; 2007). Cultural universals are common human needs and experiences, such as food, family structure, money or other economic transactions, and communication, to name a few. They offer students frameworks to support their developing understanding of social, political, and economic systems, but they also offer insight into cause-effect relationships, change and continuity, and motivations for different human actions and reactions. Because cultural universals are rooted in students' direct experiences, they provide a foundation upon which to build more sophisticated disciplinary knowledge. Observations of instruction organized around cultural universals (e.g., Alleman \& Brophy, 2001) suggest that this approach offers multiple opportunities to engage and motivate students with disabilities in the general education social studies classroom (Alleman, Knighton \& Brophy, 2007).

\section{Graphic Organizers}

A centerpiece in the CERs and cognitive strategies discussed above, graphic organizers are another means to represent facts, concepts, and relationships among ideas to support conceptual learning. Gallavan and Kottler (2007) present different types of graphic organizers that can assist students at various points during social studies classes. Before discussion and reading, graphic organizers can help teachers assess students' prior knowledge, introduce a topic, activate students' prior knowledge, provide a reason or rationale for the topic, facilitate brainstorming, and pique 
students' interest. During discussion and reading, graphic organizers can support notetaking, provide a memory aid, extend learning, highlight main ideas, and offer the teacher means to assess students' understanding and misconceptions. After reading and discussion, graphic organizers can also assess learning, reinforce or review content, provide a summary of what has been learned, and set the stage for future instruction.

Four common categories of graphic organizers are particularly suited for social studies instruction (Gallavan \& Kottler, 2007):

1. Assume and anticipate graphic organizers, such as a $\mathrm{K}-\mathrm{W}-\mathrm{L}$, are useful at the start of a lesson to help students activate their prior knowledge and provide a foundation for the topic they are about to study.

2. Position and pattern organizers, such as a timeline, help students sequence and order events and see cause-effect relationships.

3. Group and organize organizers, such as concept maps, help make explicit the structure and relationships among ideas.

4. Compare and contrast organizers, such as Venn diagrams, help students coordinate multiple perspectives or related ideas.

Technology-based tools also offer viable means of creating and using graphic organizers. Time lining software (e.g., Timerliner: http://www.tomsnyder.com/timelinerxe/index. asp) simplifies the process of data entry, ease of moving items around, and the placement of items in appropriate relation to one another. Concept-mapping software, such as Inspiration or Kidspiration (www.inspiration.com), can be used for multiple social studies activities. In our research (Okolo et al., 2002), teachers have used concept mapping in conjunction with brainstorming before the start of a unit, asking students to call out what they know about transportation or communication, for example. The teacher types a node for each idea in a concept-mapping program, which is displayed to the class on a projection system. Students and teacher then discuss how the nodes might relate to one another, creating super- and subordinate concepts and linking ideas together, which can be done "on the fly." Several studies have shown that student-generated concept mapping, based on social studies textbook passages, improves the retention and comprehension of students with disabilities (Blankenship, Ayers, \& Langone, 2005; Boon, Burke, Fore, \& Hagen-Burk, 2006; Boon, Burke, Fore, \& Spencer, 2006; Boon, Fore, Ayers, \& Spencer, 2005).

\section{Personalization}

Given the abstraction of many social studies concepts, instructional practices often attempt to relate content to students' personal lives and experiences. For example, the expanding environments framework (Hanna, 1962), which undergirds many elementary social studies curricula, engages students in investigating their own lives and communities and then applying these personal experiences to the larger world. Alleman and Brophy's Cultural Universals curriculum also relates young students' lives to larger social, political, economic, and historical concepts (Brophy \& Alleman, 2007).

Personalization may be particularly advantageous for students with disabilities, who may have more limited experience with or understanding of key social studies concepts. In our studies of a middle-school social studies unit (Ferretti et al., 2001; Okolo et al., 2002, Okolo, Ferretti, \& MacArthur, 2007), teachers and students exhibited a strong tendency to personalize the study of history. Students expressed greater interest in those topics that were relevant to their personal interests and chronological ages. For example, after generating questions they would like to explore about the 1840s, the teacher noted, "Students are interested in what life was like for kids in the $1840 \mathrm{~s}$, not in generic categories of information such as technology or communication" (Okolo et al., 2002, p. 309). Personalization can be facilitated through classroom discussions (below), and by other activities such as reading nonfiction or fictionalized accounts of young children or adolescents from other times and places, by engaging students in actual or simulated activities, and by writing journals or diaries that put students in the role of a character.

However, personalization may also limit understanding, particularly in history classes. Students' everyday lives and experiences are vastly different from most of the historical events and characters they study. Even students' understanding of historical inquiry itself can be skewed by attempts to situate it in students' personal experiences, as was the case when several students in one of our studies concluded that historical evidence is akin to criminal evidence (Ferretti et al., 2007). Interpreting history through the lens of our own experience leads to the bias of presentism (Ashby \& Lee, 1987; Judd, 1915; Wineburg, 2000), thus limiting our ability to understand people and events in the context of the times and situations in which they occurred. Hence, teachers need to both draw students into social studies through making history more personal and then help them stand back and examine the differences between then and now.

\section{Classroom Discussion}

Classroom discussion is a key feature of productive social studies instruction and offers multiple benefits for students with disabilities and their teachers (Ferretti et al., 2001; 2007; Okolo, Englert, Bouck, \& Heutsche, 2007). It 
provides access to learning that is not bound to the relatively unresponsive formats of textbooks and lectures. Discussion gives teachers a way to tailor instruction to the needs and interests of their students and to engage and motivate reluctant learners. Teachers have rich opportunities, during discussion, to stimulate students' learning by provoking them to examine and defend their opinions and by exposing them to different perspectives. And discussions provide an on-thespot means for teachers to monitor and expand students' conceptual learning (Palincsar, Magnusson, Collins \& Cutter, 2001). As one teacher reported,

\begin{abstract}
I have found, in class discussions, I have been enlightened by a student's viewpoint; something that I never thought of in that manner, it took a child to help me see a different angle. Listening to kids in the classroom has helped me become a better teacher because I have learned how to think like children think, so I can anticipate parts of lessons where I think I need to work more because I don't think the student will understand it (Okolo et al., 2002, p. 305).
\end{abstract}

Effective classroom discussion doesn't occur by chance, however; it incorporates the use of many elements associated with effective teaching practices (Morocco, 2001, Hindin, \& Mata-Aguilar, 2001) including review, definition of key terms and vocabulary, establishment of clear goals, divergent questions, repetition, invitations for participation directed to reluctant students, and revoicing and incorporating students' comments into the conversation (Okolo et al., 2007). Students benefit from disagreement, controversy, and challenges to their ideas during discussion. However, classroom environments that support all students' participation and engagement depend upon explicit norms and teacher direction. For example, as one teacher who used discussion extensively in an inclusive social studies class explained:

\begin{abstract}
In my classroom, you're allowed to challenge. You're not allowed to say "you're wrong," but you're allowed to disagree and you're allowed to challenge. Those are words you're allowed to use in my classroom-."I'd like to challenge that." And while you're listening to me challenge what you said, maybe you'll change your perspective; you'll think of something you haven't thought of before (Okolo et al., 2002, p. 302).
\end{abstract}

\section{Procedural Learning}

\section{Cognitive Strategy Instruction}

Explicit instruction in cognitive strategies involved in completing academic tasks is one of the most potent interventions for students with disabilities (e.g., Vaughn, Gersten, \& Chard, 2000). Cognitive strategy instruction addresses both procedural and conceptual learning by providing students with procedural tools that they can use in service of deeper understanding. Researchers have developed and evaluated cognitive strategies for social studies learning that include general literacy strategies and domain-specific strategies, (De La Paz \& MacArthur, 2003). Of particular note, the keyword method, discussed earlier, has helped students with learning disabilities master social studies facts and vocabulary, including United States presidents, state capitals, and content from textbooks (Brigham, Scruggs, \& Mastropieri, 1995; Mastropieri \& Scruggs, 1988; Mastropieri, Scruggs, Levin, Gaffney \& McLoone, 1985; Scruggs, Mastropieri, Brigham, \& Sullivan, 1992) and has led to better recall (Fontana, Scruggs, and Mastropieri, 2007).

Question generation strategies, in which students are taught to ask specific questions and seek their answers in the text before, during, and after reading, have been used successfully to improve students' social studies text comprehension. Questioning strategies help students locate the main idea, identify themes, summarize information, and make predictions (Wong, Wong, Perry, \& Sawatsky, 1986). In particular, Collaborative Strategic Reading (CSR) (Klingner, Vaughn \& Schumm, 1998) and reciprocal teaching (Palincsar \& Brown, 1984) have resulted in improved social studies achievement (e.g., Lederer, 2000). Each of these strategies engages students in a series of procedural steps that include the following:

1. Preview

2. Monitor comprehension

3. Locate and resolve comprehension difficulties

4. Summarize

5. Predict

Bain (2006) notes that strategies, such as Question the Author (QtA) (Beck, \& McKeown, 2002; Beck, McKeown, \& Worthy, 1995), are particularly important in helping students overcome the predisposition to accept without criticism the authority of the textbook. In one of the initial steps of this strategy, students are taught to question the author by articulating factors that might constrain the author's knowledge or purpose. Taking a critical stance, evaluating evidence, considering multiple perspectives, and recognizing potential sources of bias are key features of historical inquiry (VanSledright \& Kelly, 1998).

General literacy strategies to guide students' writing can also be useful in social studies classes. For example, Graham and colleagues (e.g., Graham \& Harris, 1989; Mason, Harris, \& Graham, 2002) have developed and evaluated a planning strategy, $P O W$ ( $P$ ick my idea, Organize ideas into a writing plan, Write and say more) and the $W$ $W-W$ Why $=2$, How $=2$ strategy for questioning and brainstorming story elements. These strategies could be useful for writing biographies or newspaper articles in a history class. Or, a student faced with writing a historically accurate but hypothetical account of experiences on the Oregon 
Trail might use the story grammar strategy, SPACE, which prompts students to include the elements of Setting, Problems, Actions, Consequences, and Emotions (De La Paz \& Graham, 1997; Troia \& Graham, 2002). Moreover, a number of writing strategies address expository or informational writing, representative of the type of writing students are expected to use when they write a letter to the editor or a position paper. For example, the DARE strategy offers an organizational framework for writing persuasive essays by prompting students to Develop a position statement, Add supporting arguments, Report and Refute counterarguments, and End with a strong conclusion (De La Paz, 2001).

A few researchers have developed discipline-specific strategies for social studies instruction. Okolo and colleagues (Okolo \& Ferretti, 1996b; Okolo, Englert, Bouck, Heutsche, \& Courtad, 2008) created strategies to assist middle school students with mild disabilities in interpreting primary written sources and images. These strategies share common features of

- identifying the author or source,

- articulating the main idea or story told by the author or artist,

- recognizing the author's purpose for creating the information,

- examining details,

- evaluating bias, and

- reflecting on the image's or text's impact on the reader or viewer.

De La Paz (2005) has developed a more comprehensive historical reasoning strategy that draws upon literature about historiography and includes instruction in sourcing (understanding the author, his or her purpose, and potential for bias), corroboration (reading multiple sources, detecting inconsistencies and missing information, and drawing inferences across sources), and taking notes based on the trustworthiness of the sources. Students, including those with disabilities, who participated in De La Paz's strategy instruction condition wrote longer, more accurate, and more persuasive essays.

Interestingly, research suggests that educators may be able to "double-dip" by teaching cognitive strategies in the social studies classroom. Studies of CSR (Klingner et al., 1998) and text-structure instruction (Williams, Nubla-Kung, Pollini, Stafford, Garcia, \& Snyder, 2007) in the context of social studies classes have demonstrated improved reading comprehension without a concomitant decrement in content knowledge. Although one might expect that time spent on strategy instruction would compete with time available for instruction on content, in these two studies, students in the strategy instruction conditions performed just as well as students who spent more time learning social studies.

\section{Literacy Software Tools}

Literacy software programs offer supported access to text through technology tools that provide procedural support for comprehension. These programs typically include text-tospeech (TTS) options, in which text can be "read" to students in a variety of voices. Students often can choose the voice of the "reader" and adjust features such as speed, volume, and pitch. Newer computer operating systems read digital text, as does Adobe Reader (for texts are created in accessible formats, see http://www.adobe.com/accessibility/?promoid=DJGVE), and Microsoft Reader (http://www. microsoft.com/Reader/default.mspx). Furthermore, other free applications, such as CLiCk, Speak (http://clickspeak. clcworld.net/), will read text from the Internet.

However, as discussed above, social studies texts are often packed with difficult vocabulary and concepts and are organized in less than optimal ways. Even when students can listen to text via a TTS feature, they may still struggle to understand and learn from it (Socol et al., in preparation). More promising is the increasing number of literacy software programs that offer an intelligent electronic reading environment (Anderson-Inman \& Horney, 2007) with specific features that support comprehension and meaningful learning. Features include vocabulary support (through online glossaries and dictionaries), note taking features, spell checkers, and other features to support reading and writing. Commonly used literacy software programs include:

AspireREADER (http://www.cast.org/products/ereader/ index.html)

Kurzweil 3000 (http://www.kurzweiledu.com/)

Read Outloud (http://www.donjohnston.com/products/ read_outloud/)

Read-Write Gold (http://www.readwritegold.com/)

WYNN Literacy Software (http://www.freedomscienti fic.com/LSG/products/wynn.asp)

Extant studies show that students with disabilities like literacy software and prefer to use it over traditional printbased text reading. However, the impact of these tools on text comprehension is unclear (Elkind, Cohen, \& Murray, 1993; Okolo, Cavalier, Ferretti, \& MacArthur, 2000; Strangman, \& Hall, 2003). Research suggests that TTS can improve the rate at which students read text (Dimmit, Hodapp, Judas, Munn, \& Rachow, 2006) and is most effective for learners who are slow readers but have strong listening comprehension (Okolo, Cavalier, Ferretti, \& MacArthur, 2000). The impact of software features, such as vocabulary support or highlighting, seems to vary with the 
degree to which students use them in a thoughtful and integrated manner, with stronger effects as students use literacy software features over time (Dimmitt et al.). Thus, educators should be aware that literacy software tools offer substantial benefits for some students, but they are not a panacea for the challenges presented by content-area texts. Rather, the teacher has a key role to play in continuing to support and teach vocabulary knowledge, comprehension strategies, and thoughtful use of literacy software features.

\section{Investigative Learning}

Learning by inquiry, or investigation, has been a key feature of education reform in science and social studies (Morocco et al., 2001). Learning by investigation draws together factual, conceptual, and procedural knowledge in a performance or product that offers an authentic experience in the social studies. Investigation provides the opportunity to integrate social studies topics in ways that promote interdisciplinary understanding. Furthermore, investigation can serve as an apprenticeship into the disciplines, as students engage in the activities of historians, geographers, civic officials, or economists. Investigative learning usually employs many of the principles of hands-on science that were discussed earlier.

Several curricular programs have been developed to support learning by investigation in social studies. These include the Decisions: Decisions series (http://www.tomsny der.com/products/Product.asp?SKU=DECDEC), produced by Tom Snyder. In these materials, students assume the role of a stakeholder or key individual in a problem or issue that entails a social studies topic (e.g., the cold war, the environment). Working in cooperative groups, they read background materials about the issue that are specific to their assigned role and then agree upon a response to the issue. Their response determines what occurs next, and, again, they receive background materials to read, discuss a response, and make a decision about subsequent action. The information gathering, discussion, and decision-making process proceeds through several cycles until the simulation is concluded with a final outcome, which is determined by prior actions and decisions. Both paper-based and technology-based versions of these materials are available. Although they seem promising for teaching social studies to students with disabilities, the reading materials are difficult, and there appears to be no research about their impact on students with learning or literacy difficulties.

Other researchers have developed instructional units around anchor videos, including To Kill a Mockingbird (Rieth, Bryant, Kinzer, Colburn, Hur, Hartman, \& Choi, 2003) and Eyes on the Prize (Gersten, Baker, Smith-Johnson, Dimino, \& Peterson, 2006). Both of these interventions included detailed analysis of the video to develop students' conceptual understanding, discussion, collaborative group investigation, and integration of information across social studies disciplines. Results showed that students with disabilities experienced increases in knowledge and reasoning and improved motivation for social studies learning.

Ferretti and colleagues (Ferretti \& Okolo, 1996; MacArthur et al., 2002; Okolo \& Ferretti, 1996a, 1996b;) have used a project-based learning approach to teach a number of different social studies topics (e.g., the American Revolutionary War, immigration, westward expansion, industrialization, and the Spanish conquest of Latin America). In this approach, students are assigned a controversial topic to investigate in a heterogeneous cooperative group of learners. Units are structured around a framework, or big idea, such as the migration and conflict schema discussed above, and students are taught to use strategies, such as compare-contrast, in analyzing both primary and secondary sources. Teachers employ both small group and whole-class discussion, and students' inquiries conclude in a project that is displayed to an audience beyond the classroom through a presentation, open house, debate, or other public event. Teachers offer direct instruction in content, teach productive group interaction and monitor group work, and set explicit standards for final products.

Results from these studies include the finding that students with disabilities make knowledge gains that are at least comparable to those of students without disabilities and favorable when compared to students who engage in traditional textbook-based learning. We also found that students' attitudes toward social studies are more positive in project-based learning conditions, and we have some evidence that students can transfer their knowledge to contemporary events and engage in more extensive reasoning and argumentation during group discussion. However, we also found the impact of a project-based approach to social studies learning is mediated by the degree to which teachers have effective classroom management skills. In classes with greater behavioral disruptions, project-based learning was not as effective as in those classrooms in which student behavior did not interfere significantly with instruction.

\section{Digital History}

The World Wide Web offers a wealth of resources to support social studies instruction (Okolo, 2005). For example, the Library of Congress (www.loc.gov) has an extensive collection that includes primary and secondary source material, lesson plans, and other activities to engage students in social studies. History Matters (www.historymatters.org) is a portal to a large number of annotated, high quality history websites. The Center for History and New Media (http:// chnm.gmu.edu), a collaborator in the production of History 
Matters, also contains a variety of digital archives and lesson plans that support instruction in United States and world history. Just about every major historical museum, national park, and large university offers websites that contain rich primary and secondary source documents about social studies topics and events.

Thus, the web gives students and teachers direct access to many of the same primary sources and data collection and analysis tools used by historians, economists, political scientists, and others who work in the social studies disciplines. Information obtained from the web is displayed in a variety of media, ranging from text to movies to music to speeches, obviating some of the challenges faced by students with reading and learning disabilities. The nonlinear manner in which students can view and organize the information retrieved from the web may facilitate understanding of multiple perspectives, a cornerstone of historical inquiry. Social studies-related sites also contain or link to communication tools, such as blogs and forums, that students can use to collaborate with one another and with individuals who have expertise in a discipline. These features enable students to become "the novice in the archive," engaging in active exploration, interpretation, and communication in ways that have previously been reserved for experts (Bass \& Rosenzweig, 1991).

However, few educators have the time needed to keep up with the rapidly evolving collections of resources on the web and to integrate them in a systematic way in the social studies classroom. Additionally, many of the investigationbased activities on social studies sites are designed for middle and high school students and may be written at levels far above the average reading level of students with disabilities. Primary source documents are notoriously difficult to interpret for students unfamiliar with the times in which they were written and with the conventions of language used at that time (e.g., Okolo \& Ferretti, 1996b). Even visual media, such as pictures and movies, which we tend to accept as more accessible than print, may not be immediately useful to students without instruction and guidance (e.g., Okolo, Ferretti, \& MacArthur, 2002).

\section{The Virtual History Museum (VHM)}

In order to take advantage of the potential of the web for social studies investigation in a classroom- and student-friendly manner, we developed a web-based learning environment, the VHM. The VHM is organized around the metaphor of a museum, in which a curator, typically a teacher (or a student, with the teacher's approval), creates an exhibit for viewers to explore or investigate. Exhibits are composed of artifacts that can be text, images, sounds, music, or videos. The curator can add explanations or other text to each artifact to provide background or other information, offer explanations, or direct the viewer's attention. In addition, because we want viewers to investigate exhibits in a goal-directed manner, each exhibit has learning activities, assigned by the curator, that require the viewer to organize, summarize, or communicate what he or she is learning from the exhibit. Learning activities include writing - such as position papers and letters to the editor-and charts and maps activities - such as Venn diagrams and compare-contrast charts.

The VHM is built around an easy-to-use interface that lets teachers import artifacts, create activities, and assemble exhibits. Or, teachers can use or edit the artifacts, activities, and exhibits that are publicly available on the site. Currently, the VHM has a searchable archive of dozens of exhibits and hundreds of artifacts, which are indexed by keywords and time periods. The VHM is available for free and runs in any browser, although we highly recommend that teachers use it with the Firefox Browser, with the CLiCk Speak text-to-speech extension. Anyone can become a guest of the VHM and view public exhibits in the museum by registering with vhm.msu.edu. Guests can become members (and use the VHM's features) by requesting an upgrade at the site.

The VHM is unique because it has built-in supports for students with reading and learning disabilities. For example, teachers can create supported versions of VHM activities in which assignments are broken down into smaller chunks, or prompts are added to guide students' task completion. Our investigations of the impact of the VHM on the knowledge and historical reasoning of middle school student with and without disabilities have yielded positive results. In one study, students with mild disabilities made knowledge gains comparable to students without disabilities and to students in an honors class. Students with disabilities were more highly engaged during social studies instruction with VHM than without (Okolo, Englert, Bouck, \& Heutsche, 2007; Okolo, Englert, Bouck, Heutsche, \& Wang, 2008). In another study with more than 300 students in two school districts, preliminary results suggest that VHM use resulted in improved knowledge and historical reasoning for students with and without disabilities, compared to outcomes for students who did not use the VHM (Okolo et al, 2008). This study also showed, however, that students' historical writing did not improve by virtue of VHM use, nor did the social studies teachers who worked with us feel competent to teach historical reading and writing strategies. These results led us to conclude that we need to design professional development for social studies teachers and continue to develop domain-specific strategies, such as those developed by De La Paz (2005) in order to better improve the outcomes of social studies instruction for student with disabilities. 


\section{Discussion}

Arguably, social studies is the most neglected subject in today's schools for students with and without disabilities. Social studies learning is a challenging endeavor, given the abstract nature of many social studies topics, the literacy challenges inherent in social studies texts, and the predispositions and limited experiences that characterize students by virtue of their age or disabilities. However, as the instructional practices reviewed above demonstrate, general and special educators and researchers are up to the challenge. Teachers can draw upon a number of research-based instructional practices to improve students' factual, conceptual, procedural, and investigative learning in social studies. Given that most of these practices have been examined in social studies classes, rather than in laboratory or specialized settings, their validity and feasibility of implementation seem promising. Equally promising is the fact that interventions have been applied to a number of different topics, although the vast majority of these have been in the context of only one of the social studies disciplines-history.

However, unlike the science instruction literature, almost all of the research about social studies instruction has been conducted with students who have mild disabilities, primarily learning disabilities. Information about social studies instruction for students with cognitive disabilities is notably absent. Furthermore, researchers have yet to investigate the sustainability or scaling up of most of the interventions discussed in this section. Additional research about the manner in which these practices unfold in the typical classroom setting would better inform and, perhaps, facilitate their broader implementation. Nor has much attention been given to the relative advantages of different approaches to social studies instruction. We've come a long way in developing and studying instructional practices that are responsive to the characteristics of learners and the demands of social studies instruction, but there is plenty more work to be done.

\section{CONCLUSIONS}

Without a doubt, the attention given to science and social studies instruction for students with disabilities has blossomed since the early 1990s. The catalysts for this increased interest are rooted in the growing inclusion of students with disabilities in general education classrooms and educational reforms such as statewide testing, No Child Left Behind, and the 1997 and 2004 IDEA reauthorizations. As we have argued, science and social studies instruction are important subjects in and of themselves but also have long-term implications for preparing students with disabilities to fulfill important roles as informed citizens and contributors to society. Thus, we consider an increased focus on these subjects a highly desirable development for students with disabilities and their teachers.

Both science and social studies classes continue to rely primarily on textbook-based instruction, and researchers have developed a variety of instructional practices that are responsive to these demands. Many of the features of these practices are similar across the content areas, although they differ in their details. In particular, approaches for teaching facts and vocabulary, mnemonic strategies, general literacy strategies, and literacy software offer effective approaches for mitigating some of the literacy, experiential, and memory challenges encountered by students with disabilities. Organizing curriculum around big ideas and themes is equally important for science and social studies, and visual representations such as graphic organizers can help students better understand concepts and relationships among them.

Consideration of effective practices in science and social studies has moved far beyond instruction in basic facts and concepts, however. Educators are beginning to pay more attention to the domain-specific knowledge, epistemological considerations, and investigative processes that are central to the science and social studies disciplines. The research and approaches discussed in this paper have shown that students with disabilities can successfully engage in inquirybased learning in both subjects, albeit with more support than might be necessary for peers without disabilities. Furthermore, responsive dialogue and discussion with teachers and peers can play an important role in shaping and advancing students' understanding of sophisticated ideas.

The body of work discussed here should provide educators with optimism about the potential of all students when they are offered effective instruction and sufficient support. Ideally, general educators will share this enthusiasm and continue to develop higher expectations and more positive attitudes toward the inclusion of students with disabilities in the general education curriculum. The practices discussed in this paper, even when developed with special needs students in mind, often benefit all students. Teacher education and professional development are key factors in promoting access and success in general education, however. Our research, as well as that of others (e.g., Van Hover \& Yeager, 2003), shows that general educators often lack knowledge of and experience in implementing instruction that benefits diverse learners in science and social studies. We look forward to future developments that will support success in science and social studies for learners with and without disabilities.

\section{REFERENCES}

Alleman, J., \& Brophy, J. (2001). Social studies excursions, Book 1: Powerful units on food, clothing, and shelter. Portsmouth, NH: Heinemann. 
Alleman, J., Knighton, B., \& Brophy, J. (2007). Social studies: Incorporating all children using community and cultural universals as the centerpiece. Journal of Learning Disabilities, 40, 166-173.

Anderson-Inman, L., \& Horney, M. A. (2007). Supported eText: Assistive technology through text transformations. Reading Research Quarterly, 42(1), 153-160.

Armbruster, B. B., \& Anderson, T. H. (1984). Structures of explanations in history textbooks, or so what if Governor Stanford missed the spike and hit the rail? Journal of Curriculum Studies, 16, 247-274.

Ashby, M. G., \& Lee, P. (1987). Children's concept of empathy and understanding in history. In C. Portal (Ed.), The history curriculum for teachers (pp. 62-88). London: Falmer Press.

Atkinson, R. C. (1975) Mnemotechnics in second-language learning. American Psychologist, 30, 821-828.

Bailey, G., Shaw, E. L., \& Hollifield, D. (2006). The devaluation of social studies in the elementary grades. Journal of Social Studies Research, 30(2), 18-30.

Bain, R. B. (2006). Rounding up the usual suspects: Facing the authority hidden in the history classroom. Teachers College Record, 108, 2080-2114.

Bakken, J. P., Mastropieri, M. A., \& Scruggs, T. E. (1997). Reading comprehension of expository science material and students with learning disabilities: A comparison of strategies. Journal of Special Education, 31, 300-324.

Bass, R., \& Rosenzweig, R. (1991, December 1). Rewiring the history and social studies classroom: Needs, frameworks, dangers, and proposals. Paper presented at the Department of Education Forum on Technology in $\mathrm{K}-12$ education: Envisioning a new future. Washington DC.

Bay, M., Staver, J., Bryan, T., \& Hale, J. (1992). Science instruction for the mildly handicapped: Direct instruction versus discovery teaching. Journal of Research in Science Teaching, 29, 555-570.

Bean, R. M., Zigmond, N., \& Hartman, D. K., (1994). Adapted use of social studies textbooks in elementary classrooms: Views of classroom teachers. Remedial and Special Education, 15, 216-226.

Beck, I. L., \& McKeown, M. G. (1991). Substantive and methodological considerations for productive textbook analysis. In J. P. Shaver (Ed.), Handbook of research on social studies teaching and learning (pp. 496-512). New York: McMillan.

Beck, I. L., \& McKeown, M. G. (2002). Questioning the author: Making sense of social studies. Educational Leadership, 60(3), 44-47.

Beck, I. L., McKeown, M. G., \& Worthy, J. (1995). Giving text a voice can improve student understanding. Reading Research Quarterly, 30(2), 220-238.

Bergerud, D., Lovitt, T. C., \& Horton, S. (1988). The effectiveness of textbook adaptations in life science for high school students with learning disabilities. Journal of Learning Disabilities, 21, 70-76.

Blankenship, T., Ayers, K., \& Langone, J. (2005). Effects of computerbased cognitive mapping on reading comprehension for students with emotional behavior disorders. Journal of Special Education Technology, 20(2), 15-23.

Boon, R., Burke, M., Fore, C., \& Hagen-Burk, S. (2006). Improving student content knowledge in inclusive social studies classrooms using technology-based cognitive organizers: A systematic replication. Learning Disabilities: A Contemporary Journal, 4(1), $1-17$.

Boon, R., Burke, M., Fore, C., \& Spencer, V. (2006). The impact of cognitive organizers and technology-based practices on student success in secondary social studies classrooms. Journal of Special Education Technology, 21(1), 5-15.

Boon, R., Fore, C., Ayers, K., \& Spencer, V. (2005). The effects of cognitive organizers to facilitate content-area learning for students with mild disabilities: A pilot study. Journal of Instructional Psychology, 32(2), 101-117.

Brigham, F. J., Scruggs, T. E., \& Mastropieri, M. A. (1992). The effect of teacher enthusiasm on the learning and behavior of learning disabled students. Learning Disabilities Research \& Practice, 7, $68-73$.

Brigham, F. J., Scruggs, T. E., \& Mastropieri, M. A. (1995). Elaborative maps for enhanced learning of content information: Uniting spatial, verbal, and imaginal information. Journal of Special Education, 28, 440-460.

Brophy, J. (1990). Teaching social studies for understanding and higher-order applications. The Elementary School Journal, 90, 351-4.17.

Brophy, J., \& Alleman, J. (2002). Primary students' knowledge and thinking about the economics of meeting families' shelter needs. American Educational Research Journal, 39, 423-468.

Brophy, J., \& Alleman, J., (2003). Primary students' knowledge and thinking about the supply of utilities (water, heat, and light) to modern homes. Cognition and Instruction, 21, 79-112.

Brophy, J., \& Alleman, J. (2006). Children's thinking about cultural universals. Mahwah, NJ: Erlbaum.

Brophy, J., \& Alleman, J. (2007). Powerful social studies for elementary students (2nd ed.). Belmont, CA: Wadsworth.

Bruner, J., Goodnow, J. J., \& Austin, G. A. (1967). A study of thinking. New York: Science Editions.

Bryant, D. P., Goodwin, M., Bryant, B. R., \& Higgins, K. (2003). Vocabulary instruction for students with learning disabilities: A review of the research. Learning Disability Quarterly, 26, 117-128.

Bulgren, J., Deshler, D. D., \& Lenz, B. K., (2007). Engaging adolescents with LD in higher order thinking about history concepts using integrated content enhancement routines. Journal of Learning Disabilities, 40(2), 121-133.

Bulgren, J. A., Deshler, D. D., \& Shumaker, J. B., (1998). Reasoning strategies and teaching routines for use in mainstream content classrooms. Final Research Report. Lawrence: University of Kansas.

Bulgren, J. A., Lenz, K. B., Schumaker, J. B., Deshler, D. D., \& Marquis, J. (2002). The use and effectiveness of a comparison routine in diverse secondary classrooms. Journal of Educational Psychology, 94, 356-371.

Bulgren, J. A., Schumaker, J. B., \& Deshler, D. D. (1994). The effects of a recall enhancement routine on the test performance of secondary students with and without learning disabilities. Learning Disabilities Research \& Practice, 9, 2-11.

Carlisle, J. (1993a). Understanding passages in science textbooks: A comparison of students with and without learning disabilities. National Reading Conference Yearbook, 42, 235-242.

Carlisle, J. F. (1993b). Selecting approaches to vocabulary instruction for the reading disabled. Learning Disabilities Research \& Practice, 8(2), 97-105.

Carlisle, J. (1999). Free recall as a test of reading comprehension for students with learning disabilities. Learning Disability Quarterly, $22,11-22$.

Cawley, J. F., Hayden, S., Cade, E., \& Baker-Krooczynski, S. (2002). Including students with disabilities into the general education science classroom. Exceptional Children, 68, 423-435. 
Cawley, J. F., Miller, J. H., \& Carr, S. C. (1990). An examination of the reading performance of students with mild educational handicaps or learning disabilities. Journal of Learning Disabilities, 23, 284-290.

Cawley, J. F., \& Parmar, R. S. (2001). Literacy proficiency and science for students with learning disabilities. Reading \& Writing Quarterly, 17, 1-5-125.

Crawford, D. B., \& Carnine, D., (2000). Comparing the effects of textbooks in eighth-grade U. S. History: Does conceptual organization of text help? Education and Treatment of Children, 23(4), $387-422$

Dalton, B., Morocco, C. C., Tivnan, T. (1997). Supported inquiry science: Teaching for conceptual change in urban and suburban science classrooms. Journal of Learning Disabilities, 30, 670-684.

Darch, C., \& Eaves, R. C. (1986). Visual displays to increase comprehension of high school learning-disabled students. The Journal of Special Education, 20, 309-318.

De La Paz, S. \& Graham, S. (1997). Effects of dictation and advanced planning instruction on the composing of students with writing and learning problems. The Journal of Educational Psychology, $89,203-222$

De La Paz, S. (2001). STOP and DARE: A persuasive writing strategy. Intervention in School and Clinic, 36(4), 234-243.

De La Paz, S. (2005). Effects of historical reasoning instruction and writing strategy mastery in culturally and academically diverse middle school classrooms. Journal of Educational Psychology, 97(2), 139-156.

De La Paz, S., \& MacArthur, C. (2003). Knowing the how and why of history: Expectations for secondary students with and without learning disabilities. Learning Disability Quarterly, 26, 142-154.

Deshler, D. D., Schumaker, J. B., Lenz, B. K., Bulgren, J. A., Hock, M F., Knight J. et al. (2001). Enhancing content-area learning by secondary students with learning disabilities. Learning Disabilities Research \& Practice, 16, 96-108.

Dimmitt, S., Hodapp, J., Judas, C., Munn, C., \& Rachow, C. (2006). Iowa Text Reader Project impacts student achievement. Closing the Gap, February/March (24), 6.

Driver, R., Asoko, H., Leach, J., Mortimer, E., \& Scott, P. (1994). Constructing scientific knowledge in the classroom. Educational Researcher, 23(7), 5-12.

Elkind, J., Cohen, K., \& Murray, C. (1993). Using computer-based readers to improve reading comprehension of students with disabilities. Annals of Dyslexia, 43, 238-259.

Ellis, E.S. (1993). Integrative Strategy Instruction: A potential model for teaching content area subjects to adolescents with learning disabilities. Journal of Learning Disabilities, 26, 358-383, 398.

Ellis, E. S. (2002). The clarifying routine: Elaborating vocabulary instruction. Retrieved October 1, 2008, from: http://www.ldonline.org/article/5759

Espin, C. A., Busch, T. W., Shin, J., \& Kruschwitz, R. (2001). Curriculum-based measurement in content areas: Validity of vocabulary-matching as an indicator of performance in social studies. Learning Disabilities Research and Practice, 16(3), 142-151.

Ferretti, R. P., MacArthur, C. D., \& Okolo, C. M. (2001). Teaching for historical understanding in inclusive classrooms. Learning Disability Quarterly, 24, 59-71.

Ferretti, R. P., MacArthur, C. D., \& Okolo, C. M. (2005). Misconceptions about history: Reflections on teaching for historical understanding in an inclusive fifth-grade classroom. In T. E. Scruggs \& M. A. Mastropieri (Eds.), Advances in learning and behavioral disabilities (Vol. 18). Cognition and learning in diverse settings (pp. 261-299). Oxford: Elsevier Sciences/JAI Press.

Ferretti, R. P., MacArthur, C. D., \& Okolo, C. M. (2007). Students' misconceptions about U.S. Westward Migration. Journal of Learning Disabilities. 145-154.

Ferretti, R. P., \& Okolo, C. M. (1996). Authenticity in learning: Multimedia design projects in the social studies for students with disabilities. Journal of Learning Disabilities, 29, 450-460.

Ferretti, R. P., \& Okolo, C. M. (1997, April). Designing multimedia projects in the social studies: Effects on students' content knowledge and attitudes. Paper presented at the Annual Meeting of the American Educational Research Association, Chicago.

Fertig, G. (2008). Using biography to help young learners understand the causes of historical change and continuity. The Social Studies, 99(4), 147-154.

Fontana, J. D., Scruggs, T., \& Mastropieri, M. (2007). Mnemonic strategy instruction in inclusive secondary social studies classes. Remedial and Special Education, 28, 345-355.

Frase-Blunt, M. (2000). High stakes testing a mixed blessing for special students. CEC Today, 7(2), 1, 5, 7, 15.

Fuchs, L. S., Fuchs, D., \& Kazdan, S. (1999). Effects of peer-assisted learning strategies on high school students with serious reading problems. Remedial and Special Education, 20(5), 309-318.

Fulk, B. J. M., Mastropieri, M. A., \& Scruggs, T. E. (1992). Mnemonic generalization training with learning disabled adolescents. Learning Disabilities Research \& Practice, 7, 2-10.

Gallavan, N. P., \& Kottler, E. (2007). Eight types of graphic organizers for empowering social studies students and teachers. The Social Studies, 98(3), 117-123.

Gersten, R., Baker, S. K., Smith-Johnson, J., Dimino, J., \& Peterson, A. (2006). Eyes on the prize: Teaching complex historical content to middle school students with learning disabilities. Exceptional Children, 72, 264-280.

Graham, S. \& Harris, K. (1989). Components analysis of cognitive strategy instruction: Effects on learning disabled students' compositions and self-efficacy. Journal of Educational Psychology, 81(3), 353-361.

Groves, F. H. (1995). Science vocabulary load of selected secondary science textbooks. School Science and Mathematics, 95, 231-235.

Hanna, P. (1962). Education: An instrument of national goals. Papers presented at the Cubberly Conference, Stanford University, New York: McGraw Hill.

Harniss, M. K., Dickson, S. V., Kinder, D., \& Hollenbeck, K. L. (2001). Textual problems and instructional strategies: Strategies for enhancing learning from published history textbooks. Reading and Writing Quarterly: Overcoming Learning Difficulties, 17(2), 127-150.

Higgins, K., Boone, R., \& Lovitt, T. C. (1996). Hypertext support for remedial students and students with learning disabilities. Journal of Learning Disabilities, 29, 402-412.

Horton, S. V., \& Lovitt, T. C. (1989). Using study guides with three classifications of secondary students. The Journal of Special Education, 22, 447-462.

Huber, R. A., \& Moore, C. J. (2002). High stakes testing and science learning assessment. Science Educator, 11, 18-23.

Hudson, P. (1996). Using a learning set to increase the test performance of students with learning disabilities in social studies classes. Learning Disabilities Research \& Practice, 11, 78-85.

Hudson, P. (1997). Using teacher-guided practice to help students with learning disabilities acquire and retain social studies content. Learning Disability Quarterly, 20, 23-32. 
Jitendra, A. K., Edwards, L L., Sacks, G., \& Jacobson, L. A. (2004). What research says about vocabulary instruction for students with learning disabilities. Exceptional Children, 70, 299-322.

Judd, C. H. (1915). The psychology of high school subjects. Boston: Ginn.

Kinder, D., \& Bursuck, W. (1991). The search for a unified social studies curriculum: Does history repeat itself. Journal of Learning Disabilities, 24, 270-275.

Kinder, D., \& Bursuck, W. (1993). History strategy instruction: Problem-solution-effect analysis, timeline, and vocabulary instruction. Exceptional Children, 59, 324-335.

King-Sears, M. E., Mercer, C. D., \& Sindelar, P. T. (1992). Toward independence with keyword mnemonics: A strategy for science vocabulary instruction. Remedial and Special Education, 13(5), 22-33.

Klingner, J. K., Vaughn, S., \& Schumm, J. S. (1998). Collaborative strategic reading during social studies in heterogeneous fourthgrade classrooms. The Elementary School Journal, 99(1), 1-22.

Lederer, J. M., (2000). Reciprocal teaching of social studies in inclusive elementary classrooms. Journal of Learning Disabilities, 33 , 91-106.

Lenz, B. K., Deshler, D. D., \& Kissam, B. R. (2004). Teaching content to all: Evidence-based inclusive practices in middle and secondary schools. Boston: Allyn \& Bacon.

Lintner, T., \& Schweder, W. (2008). Social studies in special education classrooms: A glimpse behind closed doors. Journal of Social Studies Research, 32(1), 3-9.

Lovitt, T., Rudsit, J., Jenkins, J., Pious, C., \& Benedetti, D. (1986). Adapting science materials for regular and learning disabled seventh graders. Remedial and Special Education, 7, 31-39.

Lowenthal, D. (2000). Dilemmas and delights of learning history. In P. N. Stearns, Sexias, P., \& Wineburg, S. (Ed.), Knowing, teaching, and learning history (pp. 63-82). New York: New York University Press.

MacArthur, C. D., Ferretti, R. P., \& Okolo, C. M. (2002). On defending controversial viewpoints: Debates of sixth-graders about the desirability of early 20th century American immigration. Learning Disabilities Research and Practice, 17(3), 160-172.

Marchand-Martella, N. E., Slocum, T. A., \& Martella, R. C. (Eds.). (2004). Introduction to Direct Instruction. Boston: Allyn and Bacon.

Mason, L., Harris, K., \& Graham, S. (2002). Every child has a story to tell: Self-regulated straetgy development for story writing. Education and Treatment of Children 25(4), 496-506.

Mastropieri, M. A., Berkeley, S., McDuffie, K. A., Graff, H., Marshak, L., Conners, N., et al. (in press). What is published in the field of special education? An analysis of 11 prominent journals. Exceptional Children.

Mastropieri, M. A., Emerick, K., \& Scruggs, T. E. (1988). Mnemonic instruction of science concepts. Behavioral Disorders, 14, 48-56.

Mastropieri, M., \& Scruggs, T. E. (1988). Increasing content area learning of learning disabled students: Research implementation. Learning Disabilities Research, 4, 17-24.

Mastropieri, M. A., \& Scruggs, T. E. (1994). Text-based vs. activitiesoriented science curriculum: Implications for students with disabilities. Remedial and Special Education, 15, 72-85.

Mastropieri, M. A., \& Scruggs, T. E. (2002). Effective instruction for special education (3rd ed.). Austin, TX: Pro-Ed.

Mastropieri, M. A., \& Scruggs, T. E. (2010). The inclusive classroom: Strategies for effective instruction (4th ed.). Columbus, $\mathrm{OH}$ : Prentice Hall/Merrill.
Mastropieri, M. A., Scruggs, T. E., \& Bohs, K. (1994). Mainstreaming an emotionally handicapped student in science: A qualitative investigation. In T. E. Scruggs \& M. A. Mastropieri (Eds.), Advances in learning and behavioral disabilities (Vol. 8, pp. 131-146). Greenwich, CT: JAI Press.

Mastropieri, M. A., Scruggs, T. E., Boon, R., \& Carter, K. B. (2001). Correlates of inquiry learning in science: Constructing concepts of density and buoyancy. Remedial and Special Education, 22, 130-138.

Mastropieri, M. A., Scruggs, T. E., \& Butcher, K. (1997). How effective is inquiry learning for students with mild disabilities? Journal of Special Education, 31, 199-211.

Mastropieri, M. A., Scruggs, T. E., \& Fulk, B. J. M. (1990). Teaching abstract vocabulary with the keyword method: Effects on recall and comprehension. Journal of Learning Disabilities, 23, 92-96.

Mastropieri, M. A., Scruggs, T. E., \& Graetz, J. (2005). Cognition and learning in inclusive high school chemistry classes. In T. E. Scruggs \& M. A. Mastropieri (Eds.), Advances in learning and behavioral disabilities: Vol. 18. Cognition and learning in diverse settings (pp. 107-118). Oxford: Elsevier.

Mastropieri, M. A., Scruggs, T. E., Hamilton, S. L., Wolfe, S., Whedon, C., \& Canevaro, A. (1996). Promoting thinking skills of students with learning disabilities: Effects on recall and comprehension of expository prose. Exceptionality, 6, 1-11.

Mastropieri, M. A., Scruggs, T. E. \& Levin, J. R. (1985). Maximizing what exceptional students can learn: A review of research on the keyword method and related mnemonic techniques. Remedial and Special Education, 6(2), 39-45.

Mastropieri, M. A., Scruggs, T. E., \& Levin, J. R. (1986). Direct vs. mnemonic instruction: Relative benefits for exceptional learners. Journal of Special Education, 20, 299-308.

Mastropieri, M. A., Scruggs, T. E., \& Levin, J. R. (1987). Learning disabled students' memory for expository prose: Mnemonic vs. nonmnemonic pictures. American Educational Research Journal, 24, 505-519.

Mastropieri, M. A., Scruggs, T. E., Levin, J. R., Gaffney, J., \& McLoone, B. (1985). Mnemonic vocabulary instruction for learning disabled students. Learning Disability Quarterly, 8, 57-63.

Mastropieri, M. A., Scruggs, T. E., Mantzicopoulos, P. Y., Sturgeon, A., Goodwin, L., \& Chung, S. (1998). "A place where living things affect and depend on each other": Qualitative and quantitative outcomes associated with inclusive science teaching. Science Education, 82, 163-179.

Mastropieri, M. A., Scruggs, T. E., Norland, J. J., Berkeley, S. McDuffie, K., Tornquist, E. H., \& Connors, N. (2006). Differentiated curriculum enhancement in inclusive middle school science: Effects on classroom and high-stakes tests. Journal of Special Education, 40, 130-137.

Mastropieri, M. A., Scruggs, T. E., \& Whedon, C. (1997). Using mnemonic instruction to teach information about U.S. presidents: A classroom-based investigation. Learning Disability Quarterly, 20, 13-21.

Mathes, P. G., Howard, J. K., Allen, S., \& Fuchs, D. (1998). Peerassisted learning strategies for first-grade readers: Making early reading instruction more responsive to the needs of diverse learners. Reading Research Quarterly, 33, 62-95.

McCarthy, C. B. (2005). Effects of thematic-based, hands-on science teaching versus a textbook approach for students with disabilities. Journal of Research in Science Teaching, 42, 245-263. 
McDuffie, M. A., Mastropieri, M. A., \& Scruggs, T. E. (2007, April). Differential effects of co-teaching and peer-mediated instruction: Results for content learning and student-teacher interactions. Paper presented at the annual meeting of the American Education Research Association, Chicago.

McKeown, M. G., \& Beck, I. L., (1988). Learning vocabulary: Different ways for different goals. Remedial and Special Education, 9(1), 45-52.

Meyers, M. P., \& Savage, T. (2005). Enhancing student comprehension of social studies material. Social Studies, 96, 18-24.

Morocco, C. C., Hindin, A., \& Mata-Aguilar, C. (2001). Building a deep understanding of literature with middle-grade students with learning disabilities. Learning Disability Quarterly, 24(1), 47-58.

National Council for the Social Studies (2008), Expectations of Excellence: Curriculum Standards for Social Studies-Executive Summary. Retrieved September 14, 2008, from: http://www.socialstudies.org/standards/execsummary/

Nelson, J. R., Smith, D. J., \& Dodd, J. M. (1992). The effects of teaching a summary skills strategy to students identified as learning disabled on their comprehension of science text. Education \& Treatment of Children, 15, 228-243.

Okolo, C. M. (2005). Technology and social studies instruction for students with mild disabilities. In D. Edyburn, K. Higgins, \& R. Boone (Eds.), Handbook of special education technology research and practice (pp. 623-642). Whitefish Bay, WI: Knowledge by Design.

Okolo, C. M., Cavalier, A. R., Ferretti, R. P., \& MacArthur, C. A. (2000). Technology, literacy, and disabilities: A review of the research. In R. Gersten, E. P. Schiller, \& S. Vaughn (Eds.), Contemporary special education research: Syntheses of the knowledge base on critical instructional issues (pp. 179-250). Mahwah, NJ: Erlbaum.

Okolo, C. M., Englert, C. S., Bouck, E., \& Heutsche, A. (2007). Webbased history learning environments: Helping all students learn and like history. Intervention in School and Clinic, 43, 3-11

Okolo, C., Englert, C. S., Bouck, E. C., Heutsche, A., \& Courtad, C. A. (2008, January). Is More Better? Web-Based History Instruction for Diverse Learners. Paper presented at the Technology, Reading \& Learning Diversity Conference. San Francisco, CA.

Okolo, C. M., Englert, C. S., Bouck, E. C. Huetsche, A., \& Wang, H. (2008). The Virtual History Museum: Learning American History in diverse eighth grade classrooms. Manuscript submitted for publication.

Okolo, C. M., \& Ferretti, R. P. (1996a). Knowledge acquisition and multimedia design projects in the social studies for students with learning disabilities. Journal of Special Education Technology, 13(2), 91-103.

Okolo C. M., \& Ferretti, R. P. (1996b). The impact of multimedia design projects on the knowledge, attitudes, and collaboration of students in inclusive classrooms. Journal of Computing in Childhood Education, 7, 223-252.

Okolo, C. M., Ferretti, R. P., \& MacArthur, C. A. (2002). Westward expansion and the ten-year-old mind: Teaching for historical understanding in a diverse classroom. In J. Brophy (Ed.), Social Constructivist Teaching, 9 (pp. 299-331). Elsevier Science Ltd.

Okolo, C. M., Ferretti, R. P., \& MacArthur, C. A. (2007). Talking about history: Discussions in a middle-school, inclusive classroom. Journal of Learning Disabilities, 40, 154-166.

Palincsar, A. S. \& Brown, A. L., (1984). Reciprocal teaching of comprehension monitoring activities. Cognition and Instruction, 1, 117-175.
Palincsar, A. S., Collins, K. M., Marano, N. L., \& Magnusson, S. J. (2000). Investigating the engagement and learning of students with learning disabilities in guided inquiry science teaching. Language, Speech, and Hearing Services in Schools, 31, 240-251.

Palincsar, A. S., Magnusson, S. J., Collins, K., \& Cutter, J. (2001). Making science accessible to all: Results of a design experiment in inclusive classroom. Learning Disability Quarterly, 24(1), 15-32.

Paxton, R. J. (1999). A deafening silence: History textbooks and the students who read them. Review of Educational Research, 69, 315-339.

Rieth, H. J., Bryant, D. P., Kinzer, C. K., Colburn, L., Hur, S., Hartman, P., \& Choi, H. S. (2003). An analysis of the impact of anchored instruction on teaching and learning activities in two ninth grade classrooms. Remedial and Special Education, 24, 173-184.

Schmidt, W. Houang, R., \& Cogan, L (2002). A coherent curriculum: The case of mathematics. American Educator, 26(2), 1-18.

Scruggs, T. E. (2004, March). Science for students with disabilities: Good for students, good for science! Paper presented at the Secretary's Summit on Science, U.S. Department of Education, Washington, DC. Retrieved April 18, 2008, from http://www.ed.gov/ rschstat/research/progs/mathscience/scruggs.html

Scruggs, T. E., \& Mastropieri, M. A. (1992a). Classroom applications of mnemonic instruction: Acquisition, maintenance, and generalization. Exceptional Children, 58, 219-229.

Scruggs, T. E., \& Mastropieri, M. A. (1992b). Effective mainstreaming strategies for mildly handicapped students. Elementary School Journal, 92, 389-409.

Scruggs, T. E., \& Mastropieri, M. A. (1993). Current approaches to science education: Implications for mainstream instruction of students with disabilities. Remedial and Special Education, 14(1), 15-24.

Scruggs, T. E., \& Mastropieri, M. A. (1994a). The construction of scientific knowledge by students with mild disabilities. Journal of Special Education, 28, 307-321.

Scruggs, T. E., \& Mastropieri, M. A. (1994b). Successful mainstreaming in elementary science classes: A qualitative investigation of three reputational cases. American Educational Research Journal, 31, 785-811.

Scruggs, T. E., \& Mastropieri, M. A. (1995). Science and mental retardation: An analysis of curriculum features and learner characteristics. Science Education, 79, 251-271.

Scruggs, T. E., \& Mastropieri, M. A. (2000). The effectiveness of mnemonic instruction for students with learning and behavior problems: An update and research synthesis. Journal of Behavioral Education, 10, 163-173.

Scruggs, T. E. \& Mastropieri, M. A. (2007). Science learning in special education. The case for constructed vs. instructed learning. Exceptionality, 15, 57-74.

Scruggs, T. E., Mastropieri, M. A., Bakken, J. P., \& Brigham, F. J. (1993). Reading vs. doing: The relative effectiveness of textbookbased and inquiry-oriented approaches to science education. Journal of Special Education, 27, 1-15.

Scruggs, T. E., Mastropieri, M. A., Berkeley, S., \& Graetz, J. (in press). Do special education interventions improve learning of secondary content? A meta-analysis. Remedial and Special Education.

Scruggs, T. E., Mastropieri, M. A., Brigham, F. J., \& Sullivan, G. S. (1992). Effects of mnemonic reconstructions on the spatial learning of adolescents with learning disabilities. Learning Disability Quarterly, 15, 154-162.

Scruggs, T. E., Mastropieri, M. A., Levin, J. R., \& Gaffney, J. S. (1985). Facilitating the acquisition of science facts in learning disabled students. American Educational Research Journal, 22, 575-586. 
Scruggs, T. E., Mastropieri, M. A., \& Sullivan, G. S. (1994). Promoting relational thinking skills: Elaborative interrogation for mildly handicapped students. Exceptional Children, 60, 450-457.

Scruggs, T. E., Mastropieri, M. A., Sullivan, G. S., \& Hesser, L. S. (1993). Improving reasoning and recall: The differential effects of elaborative interrogation and mnemonic elaboration. Learning Disability Quarterly, 16, 233-240.

Scruggs, T. E., Mastropieri, M. A., \& Wolfe, S. (1995). Scientific reasoning of students with mental retardation: Investigating preconceptions and conceptual change. Exceptionality, 5, 223-244.

Simpkins, P. M., Mastropieri, M. A., \& Scruggs, T. E. (in press). Differentiated curriculum enhancements in inclusive 5th grade science classes. Remedial and Special Education.

Socol, I., Okolo, C., \& Feyen, S. (in preparation). Text to speech software and social studies text: What difference does it make?

Spoehr, K. T., \& Spoehr, L. W. (1994). Learning to think historically. Educational Psychologist, 29(2), 71-77.

Strangman, N., \& Hall, T. (2003). Text transformations. Wakefield MA: National Center for Accessing the General Curriculum.

Sullivan, G. S., Mastropieri, M. A., \& Scruggs, T. E. (1995). Reasoning and remembering: Coaching thinking with students with learning disabilities. Journal of Special Education, 29, 310-322.
Tocci, S., \& Viehland (1996). Holt chemistry: Visualizing matter. New York: Holt, Rinehart, \& Winston.

Troia, G., \& Graham, S. (2002). The effectiveness of a highly explicit, teacher-directed strategy instruction routing: Changing the writing performance of students with learning disabilities. Journal of Learning Disabilities, 35, 290-305.

Twyman, T., \& Tindal, G. (2006). Using a computer-adapted conceptually based history text to increase comprehension and problemsolving skills of students with disabilities. Journal of Special Education Technology, 21(2), 5-16.

Van Hover, S. D., \& Yeager, E. A., (2003). Secondary history teachers and inclusion of students with disabilities: An exploratory study. Journal of Social Studies Research, 27(1), 36-44.

VanSledright, B. A. (2002). Confronting history's interpretive paradox while teaching fifth graders to investigate the past. American Educational Research Journal, 39(4), 1089-1115.

VanSledright, B. A., \& Kelly, C. (1998). Reading American History: The influence of multiple sources on six fifth graders. The Elementary School Journal, 98, 239-265.

Vaughn, S., Gersten, R., \& Chard, D. J. (2000). The underlying message in LD intervention research: Findings from research syntheses. Exceptional Children, 67(1), 99-114.

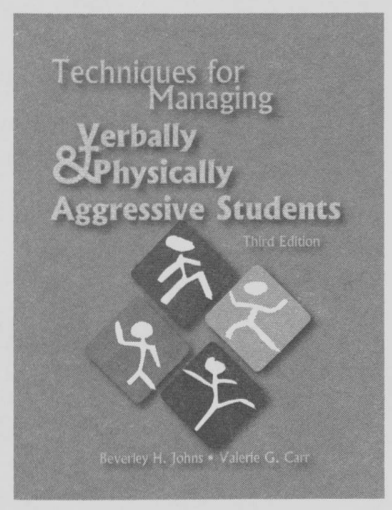

\section{Techniques for Managing Verbally \& Physically Aggressive Students} Third Edition

\section{BEVERLEY H. JOHNS AND VALERIE G. CARR}

The latest edition of this classic book incorporates new strategies for handling violence and inappropriate behavior in our schools, including the implications of new technologies like cell phones, social networking, and cyberbullying. The authors provide how-to information and step-by-step methods for working with disciplinary problems and aggression within the school setting. They focus specifically on techniques for breaking up fights, intervening in bullying, and working with students who talk back and refuse to do their work.

These classroom management techniques provide tangible results. Strategies for school-wide behavior management and community and parent involvement provide an integrated and comprehensive approach to addressing violence in our schools.

\section{LOVE PUBLISHING COMPANY}

9101 East Kenyon Avenue, Suite 2200

Denver, Colorado 80237

$303-221-7333$ • 303-221-7444 (fax)

\section{CONTENTS}

I. Facing the Challenge

2. The Classroom Climate

3. Ineffective Classroom Management Techniques

4. Successful Behavior Management

5. Behavioral Intervention Plans

6. Understanding Aggression

7. Dealing With Aggressive Behavior

8. Verbally Dealing With Aggression

9. Use of Time-Out

10. Bully-Proofing Your Classroom

II. Dealing With Physical Aggression

12. Breaking Up Fights

13. Police Intervention and Community Agency Involvement

14. Working Effectively With Parents

15. Administrative Issues

Appendixes 
Veit, D. T., Scruggs, T. E., \& Mastropieri, M. A. (1986). Extended mnemonic instruction with learning disabled students. Journal of Educational Psychology, 78, 300-308.

Ward-Lonergan, J. M., Liles, B. Z., \& Anderson, A. M. (1999). Verbal retelling abilities in adolescents with and without language-learning disabilities for social studies lectures. Journal of Learning Disabilities, 32(3), 213-22.

Williams, J. P., Nubla-Kung, A. M., Pollini, S., Stafford, K. B., Garcia, A., \& Snyder, A. E. (2007). Teaching cause-effect text structure through social studies content to at-risk second graders. Journal of Learning Disabilities, 40(2), 111-120.

Wineburg, S. (2000). Making historical sense. In P. N. Stearns, P. C. Seixas, \& S. S. Wineburg (Eds.), Knowing, teaching, and learning history (pp. 306-325). New York: NYU Press.

Wineburg, S. (2001). Historical thinking and other unnatural acts. Philadelphia: Temple University Press.
Wineburg, S., \& Grossman, P. (2001). Affect and effect in cognitive approaches to instruction (pp. 479-492). In D. K. S. Carver (Ed.), Cognition and instruction: The 30th Carnegie Symposium on Cognition. Mahwah, NJ: Lawerence Erlbaum

Wolgemuth, J. R., Cobb, R. B., \& Alwell, M. (2008). The effects of mnemonic interventions on academic outcomes for youth with disabilities: A systematic review. Learning Disabilities Research \& Practice, 23, 1-10.

Wong, B. L., Wong, R., Perry, N., \& Sawatsky, D. (1986). The efficacy of a self-questioning summarization strategy for use by underachievers and learning disabled adolescents in social studies. Learning Disability Focus, 2, 20-35.

Yager, R. E. (1983) The importance of terminology in teaching K-12 science. Journal of Research in Science Teaching, 20, 577-588.

\section{PERMISSIONS AND COPYRIGHT}

All rights are reserved. No part of this publication may be reproduced, photocopied, faxed, stored in a retrieval system, or transmitted in any form or by any means, electronic, mechanical, recording or otherwise, without the prior written permission of the publisher.
Back issues are available for sale. Reproduction requires permission and payment of fees. It is illegal and a violation of federal copyright law to reproduce this publication without permission. Direct all inquiries to the permissions editor. 